\title{
Environmental Distribution of Clay Minerals in North West Subiyah Area, Kuwait: Compositional Variation and Application
}

\author{
Ahmed M. Dakrory ${ }^{1,2}$, Ahmad Rashed Al Rashed2, Fahad A. H. Alkandari \\ ${ }^{1}$ Minia University, Faculty of Science, Geology Department, Minia, Egypt \\ ${ }^{2}$ Science Department, College of Basic Education, Public Authority for Applied Education and Training (PAAET), \\ Adailiya, Kuwait \\ ${ }^{3}$ Art Education Department, College of Basic Education, Public Authority for Applied Education and Training (PAAET), \\ Adailiya, Kuwait \\ Email: am.morsy@paaet.edu.Kw
}

How to cite this paper: Dakrory, A.M., Al Rashed, A.R. and Alkandari, F.A.H. (2018) Environmental Distribution of Clay Minerals in North West Subiyah Area, Kuwait: Compositional Variation and Application. International Journal of Geosciences, 9, 179-206. https://doi.org/10.4236/ijg.2018.93012

Received: November 3, 2017

Accepted: March 27, 2018

Published: March 30, 2018

Copyright (C) 2018 by authors and Scientific Research Publishing Inc. This work is licensed under the Creative Commons Attribution International License (CC BY 4.0).

http://creativecommons.org/licenses/by/4.0/

\section{Open Access}

\begin{abstract}
The main objective of this paper is to study the mineralogical composition and the environmental conditions of the Subiyah clay to be used for crafting pottery and technological behaviour that allows the evaluation of the applicability of the clay deposits in manufacturing new ceramic products at Kuwait. This research could help artists, crafters of potters, and ceramic manufactures in Kuwait to depend on inland clay and this makes it easier for more production in ceramic and pottery in the future. All this could enhance the cultural of ceramic in teaching or producing it in Kuwaitfor the first time. For that purpose, six stations were selected at North-eastern part (Subiyah area) of Kuwait for clay investigation. X-ray Diffraction method (XRD) was led to identify mineralogical composition of samples; S1, S2, S3, S4A, S4B, and S6 were quartz, Calcite (Caco3), Dolomite, Illite and Clinochlore. Whereas; Quartz, Calcite Dolomite, Palygorskite, Nontronite and Clinochlore were recorded at S5 and S7. Clay mineralogical and environmental studies at our study area proved that, crafter can depend on Subiyah clay better than importing it from abroad.
\end{abstract}

\section{Keywords}

Subiyah, Clay Deposits, X-Ray Diffraction, Ceramic Tiles, Ecology

\section{Introduction}

Ceramic behaviour of some clay deposits from different provinces all over the 
world was subjected to intensive studies [1] [2]. This study was focused on the properties of ceramic clays from Subiyah area Northern Kuwait for the first time. This work is considering as the first to discover a ceramic industry within this province. The clays used for manufacturing traditional ceramic handicrafts at Kuwait come from England, India and China. Clay deposits of Subiyah are Quaternary materials deposited during different episodes by the Forat River (Iraq). The relationship between the mineralogical composition of the raw materials and phase changes taking place during their sintering under different conditions has been studied by different authors [3] [4] [5].

This study results from the necessity of the Kuwait ceramic industry to locate clays of high plasticity that additionally possess a high degree of cohesion upon drying and wide verification ranges; therefore, there is great interest in their ceramic behaviour. There are no previous studies exist about these non-exploited clay deposits in Subiyah province. This is the first time that the applicability of these clays as a raw material for the ceramic industry has been tested.

\subsection{Literature Review}

The most abundant, ubiquitous, and accessible material on the earth crust is clay [6]. Clay is simply defined as earth or soil that is plastic and tenacious when moist becomes permanently hard when baked or fired. It consists of a group of hydrous aluminosilicate minerals formed by the weathering of feldspathic rocks, such as granite. Individual mineral grains are microscopic in size and shaped like flakes. This makes their aggregate surface area much greater than their thickness and allows them to take up large amounts of water by adhesion, giving them plasticity and causing some varieties to swell (expandable clay). Common clay is a mixture of kaolin, or china clay (hydrated clay), and the fine powder of some feldspathic mineral that is anhydrous (without water) and not decompose. Using clayey raw minerals in art craft and ceramic production have been extensively studied, particularly in the fields of industrial ceramic applications around the World [7]-[19] and archaeological ceramics [20]-[26].

\subsection{Geological Setting}

Kuwait lies along the north-western corner of the Arabian Gulf, bordered by Saudi Arabia in the south, Iraq to the north and west and the Arabian Gulf to the east. The surface topography is about $17,818 \mathrm{~km}^{2}$ and about seven Islands scattered off along the coast of Kuwait (Figure 1). Authors had already chosen studied stations according to the difference in morphological change noticed across the northern part of Kuwait and a quantity of rainfall during last years.

The surface of Kuwait is marked by undulating gravel-covered plains that slope gently towards the Gulf. In general, the surface of Kuwait is flat sand desert that can divide into north and south part. The north part is hard flat with shallow depressions and low hills running from north-west to south west. The principle escarpment is in the north region are Jal Az-Zour escarpment "with $145 \mathrm{~m}$, 


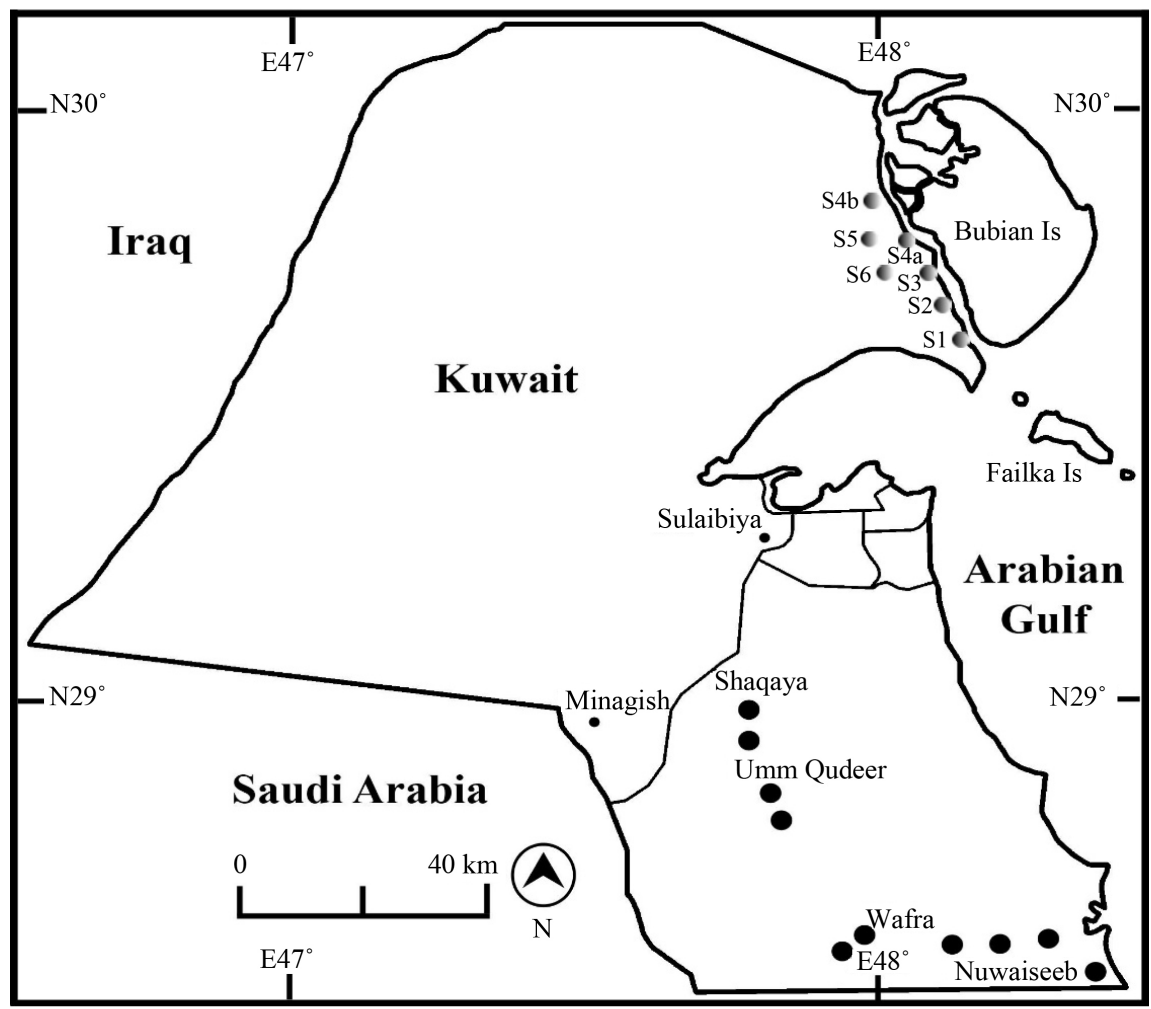

Figure 1. Kuwait Map showing location of studied stations (S1, S2, S3, S4, S5, S6 and S7).

height" and Al-Liyahv ridge "with $138 \mathrm{~m}$, height" [27]. The south part is treeless plain covered by sand, the Al-Ahmadi hill " $125 \mathrm{~m}$, heights" is the sole exception to the flat terrain. In addition to wadi Al-Batin, Ash-shaqq is another major valley, a portion of which lies within the south part of the country. Kuwait is located on the Arabian Plate between the Precambrian Arabian Shield to the west and the Zagros Fold belt to the east. Compared to these neighbouring structural terranes relatively simple structural elements may be expected. However, many publications describe an unexpected complexity, particularly relating to surface geology [27] [28] [29] [30]; gravity structure [31] [32] [33] and oil field structures [34]-[46]. This paper describes the major structural elements identified onshore Kuwait and illustrates and discusses the specific characteristics of selected structural elements using gravity, seismic and we 11 data. The location and names the structures commonly used by petroleum geologists and hydro-geologists in Kuwait and some important observations concerning distinctive suites of structural trends are presented and related to the regional structure.

\subsection{Geomorphology of Kuwait}

Geological the land of Kuwait consists of flat-lying Tertiary rocks over laying the gently folded cretaceous and Jurassic formations [29]. Rock types exposed in outcrops include the Eocene Dammam formation. The Oligocene Ghar formation and the Miocene and Pliocene Mutla and Jal-Az-zor formations (Figure 2). The Dammam formation is white fine grinned cherty limestone that shows some 


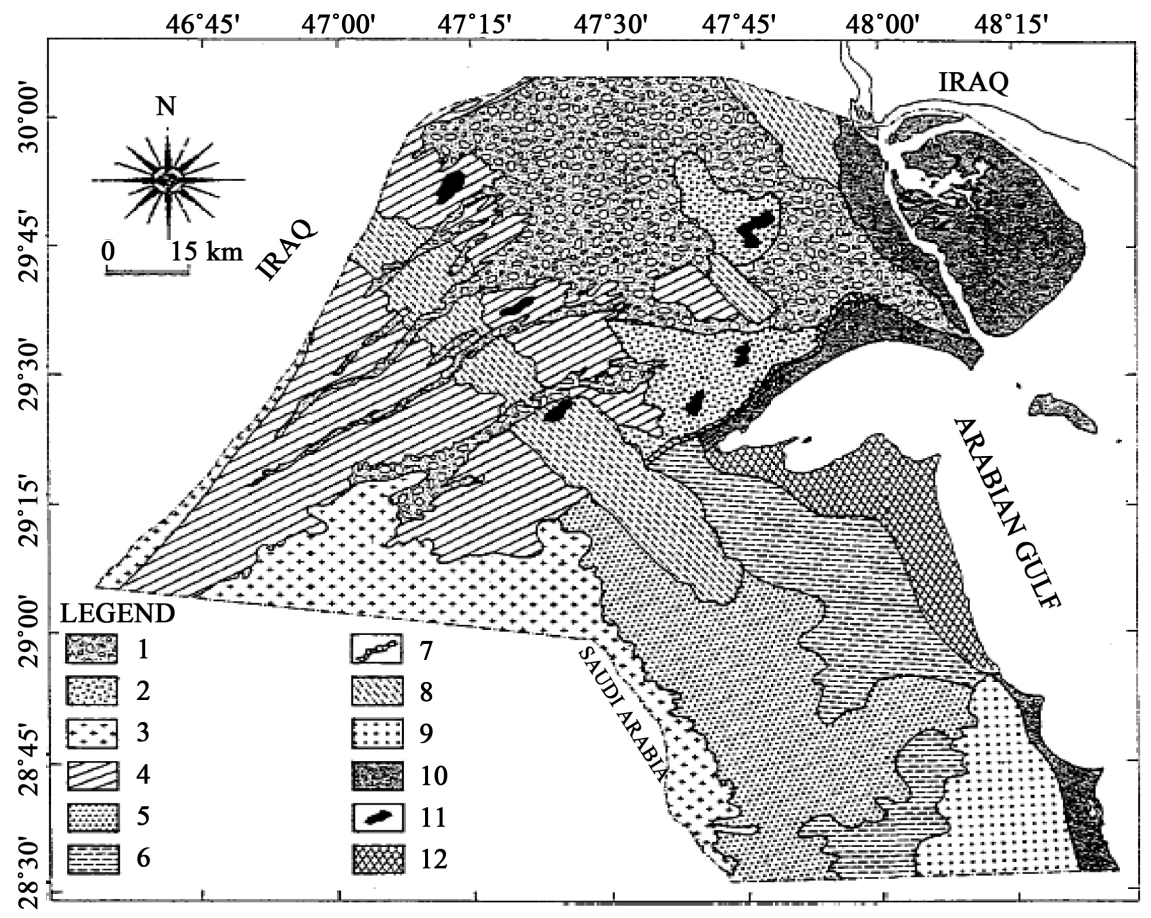

Figure 2. Geomorphological characteristics and surface deposits of Kuwait [49]. 1 = Gravel lag, 2 = Desert 3 = Desert floor deposits covered by siliciclastic granule lag, pebbly and granule lag rich in calcrete debris, $4=$ Deflated rugged sand sheets, $5=$ Active sand sheets, $6=$ Smooth sand sheets, $7=$ Fall dunes, $8=$ Barchan dunes, $9=$ Barchanoid ridges, $10=$ Coastal plain deposits, $11=$ Playa deposits, $12=$ Urban areas.

karst development and at its contact with younger sediments, which is an indication of sub-aerial exposure and erosion. The Ghar, Mutla and Jal-Az-Zor formations are primarily composed of calcareous sandstones. Sunday lime stones, clay and sand. Unconsolidated sands constitute nearly half of these deposits [47]. The structure of the Dammam formation has directly left an impression on the surface as morph structural forms and in directly controlled the geomorphic forms of the overlying sediments [48]. Completing the section above the Ghar, Mutla and Jal Az-zour formation is Dibdibba formation, divided based on grain size into an upper and lower member (Figure 3 ) the lower member is gritty sand stone, whereas the upper member is coarser, pebblier sand stone. Quaternary deposits include lag gravel which blanket much of the interior of Kuwait and coastal deposits include unconsolidated marine sands, mud flats and supratidal sabkha surface [29].

In general, north Kuwait is largely covered by a gravel plain. The predominated of this unit in Kuwait is mainly attributed to the recurrence of the gravel Dibdibba formation which out crops in north Kuwait and south Iraq and acts as a protective lager stabilizing the desert surface from wind evasion [50]. Conversely, south Kuwait covered by a sandy plain composed of smooth and rugged, vegetable sand sheets. The recent surface deposits of Kuwait are classified into eleven major classes per their textural characteristics and field occurrences, normally 1) aeolin 2) residual 3) playa lake 4) playa 5) talus 6) alluvial fans 7) 


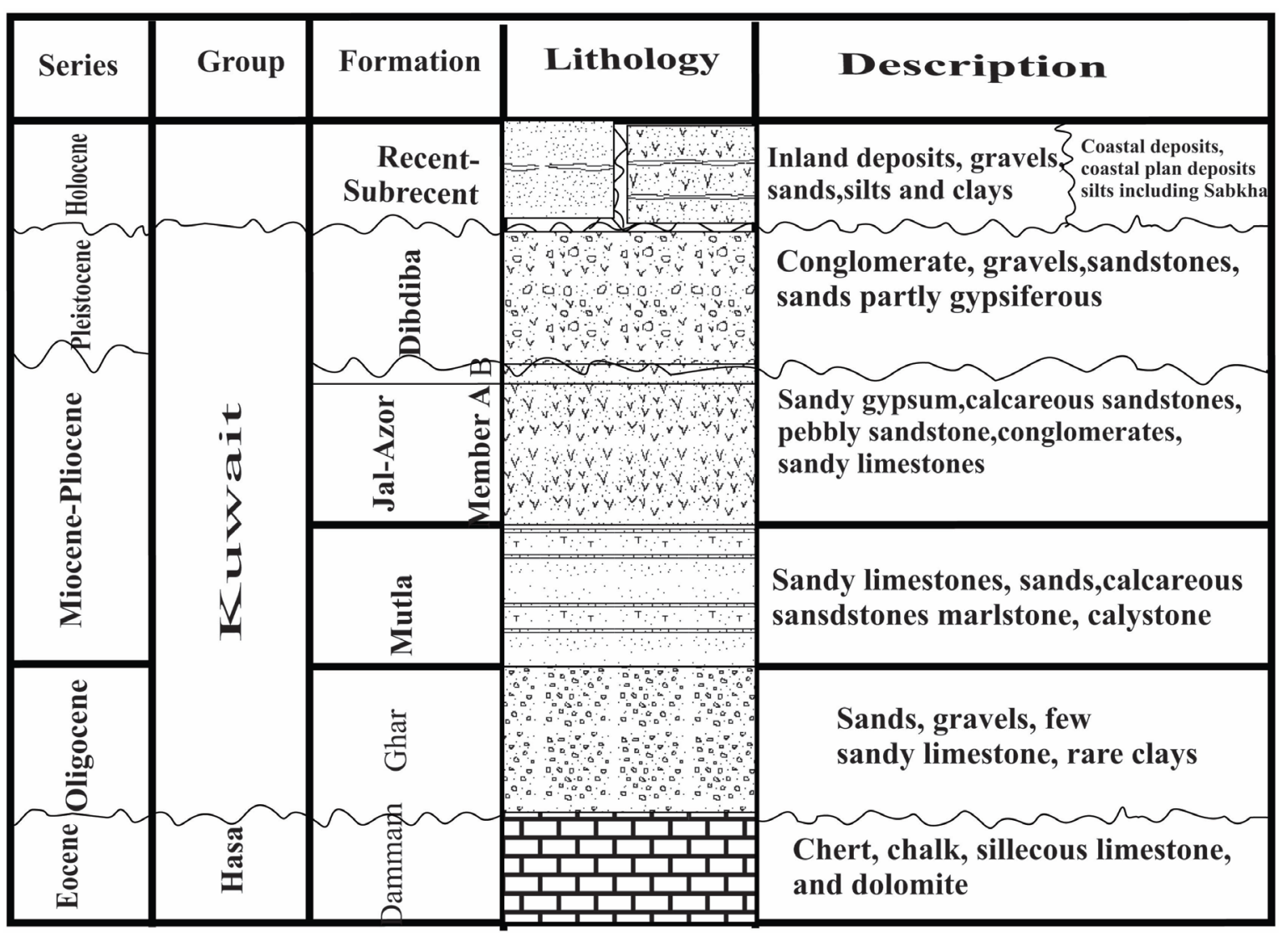

Figure 3. Stratigraphic column of Kuwait [Modified after [47]].

tidal flat 8) beaches 9) calcrete 10) evaporate 11) wadi and desert plain [49].

The distribution of surface sediments is highly controlled by several mechanisms. Firstly, wind plays, a major role in distribution Quaternary and recent Aeolian deposits along the dominated direction form the north-northwest, the dune fields and sands sheets are clearly oriented in this direction. Secondly, water-laid deposits are visible along the wadi channels where high amounts of pebbles and gravels from a gravel lag along the wadi tributary system (Figure $2 \&$ Figure 3). Thirdly, evaporate (ca 804) and (ca 504.21120) and salt deposited are formed along the coast and on land where the evaporation rate is highly during the summer.

The main two sources of sediments in the Northern Kuwait: the Aeolian deposition and the in-situ precipitation in the form of sabkhas (coastal sabkhas). Aeolian transportation, as mentioned by [51], comes from several locations. Another potential source of dust is the southern area of Iraq, where an area of about $9000 \mathrm{~km}^{2}$ (southern marshes) was drained, resulting in the occurrence of dry lands that are vulnerable to the dominant NW-SE wind direction creating dust storms that settle over the northern part of the Arabian Gulf.

\subsection{Climate}

The climate of Kuwait is characterized by extremely hot, dry summer with aver- 
age maximum daily temperature of $59^{\circ} \mathrm{C}$ and mild to cool in winter in which temperature of $1^{\circ} \mathrm{C}$ occur. The annual rain fall is 3 to more than 13 inches and averages between 2 and 5 inches. Evaporation gently dominates over the whole climatic year. The general movement of ground water is up word. It leads to concentration of soluble materials near the surface, enriching the top layers in gypsum, halides and calcium carbonate. The relative humidity is high in December and January, with average maximum of $85 \%$. Summer humidity is generally less than $45 \%$. The frequent winds from the north-west are cool in winter and spring and hot in summer. Dust-storms (Toz) lasting at times for several days through the year.

\subsection{Stratigraphy}

\section{Recent Beds (Quaternary)}

Rocks ranging in age from early Miocene to Recent are exposed on the surface throughout the State of Kuwait. The very low dips and similarity of lithology make correlation of formations difficult, as marker beds can be traced accurately for only short distances. Along the Jal-Az-Zor escarpment three formations can be recognized, owing to the presence of fossiliferous clays of the Lower Fars Formation which separate the overlying Dibdibba Formation from the Ghar Formation. Where the Lower Fars cannot be recognized, no subdivision is possible, and the entire sequence is called the Kuwait Group. Recent deposits within Kuwait consist of the following types:

Beach deposits are composed of reworked sandstone from the Kuwait Group; these sands may be cemented with calcium carbonate and are current bedded. Some oolitic limestones and shelly limestones also occur. The fossils within these beds have been correlated with present species. Extensive deltaic and tidal mudflats are found in north-eastern Kuwait, Bubiyan Island, and along the north shore of Kuwait Bay. These are composed predominantly of plastic clay and silt having a high saline content. The material is considered by the author and others to have been deposited by the Tigris-Euphrates Kiver system.

Deposits formed in inland drainage basins are usually very fine silt and clay with a variable percentage of sand and a very high salt content. Windblown sand is common.

\section{Clay Minerals and Its Environment}

Clay-based materials occur both in the plain and river areas [52]. The term "clay" refers to a naturally occurring material that composed primarily of fine-grained minerals, which is generally plastic at appropriate water contents and susceptible to hardening when fired at high temperature [53]. Although clay usually contains phyllosilicates, it may contain other materials that could impart plasticity when wet and harden when fired. However, associated phases in clay may include organic matter and materials that do not impart plasticity Clay minerals can be categorized into four subgroups: 1) kaolinite; 2) smectite 
(montmorillonite, saponite); 3) mica (illite), and 4) chlorite [54] [55] [56].

Clay minerals are seldom mono-mineral and have no genetic significance, as it is used for residual weathering products, hydrothermally altered products, and sedimentary deposits [57]. These minerals occur under a limited range of geologic environments which include soil horizons, continental and marine sediments, geothermal fields, volcanic deposits, and weathering rock formations. In general, they form where rocks are in contact with water, air, or steam and the type of clay however is controlled by the composition of pre-existing rock mineralogy [58].

\section{Materials and Methods}

\subsection{Sampling and Site Environmental Investigation}

Six stations were selected for soil samples from Subiyah area, Northern Kuwait. Samples from modern freshwater and coastal marine depositional environments were chosen for the inter-laboratory comparison. Samples were collected from depths of $0.2 \mathrm{~m}$ to $0.4 \mathrm{~m}$ below the ground surface (see map Figure 1 \& Figure 4). Recent clayey bed in our studied stations was formed because of common weathering, diagentic, and marine conditions. Samples were trimmed carefully to slightly oversize the brass liner sampler which was pushed in the soil and slightly sampled. After extraction, the tubes were sealed with special rubber caps and transported to the laboratory and preserve din a humidity-controlled cabinet.

\section{Analytical Methods}

X-ray diffraction (XRD) was performed on 7 (see Figures 5-12) samples using Siemens D5000 Diffractometer. Representative samples of the clays were

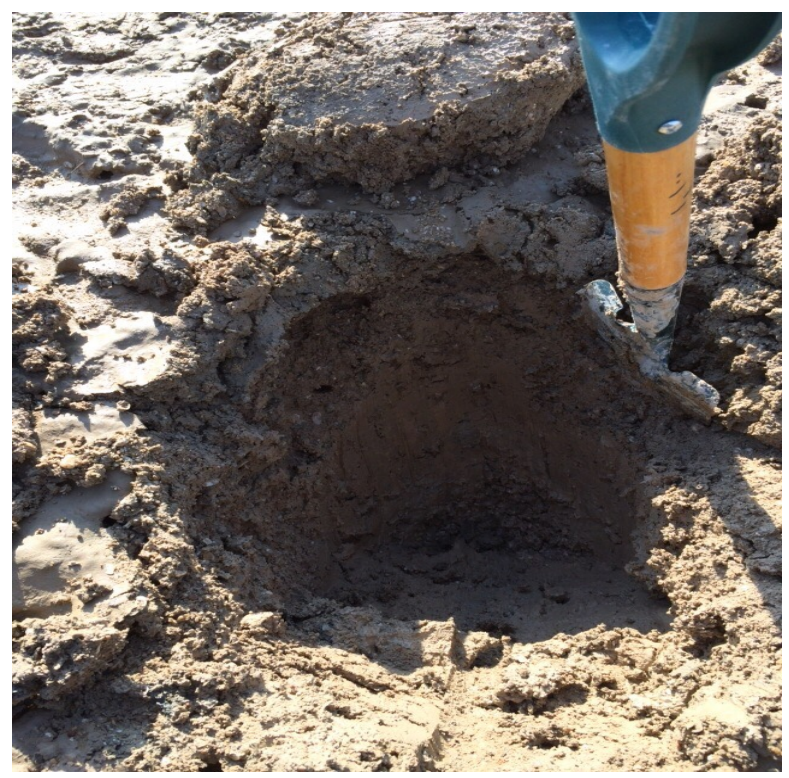

Figure 4. Recent clayey bed intercalated with sand near Subiyah beach. 


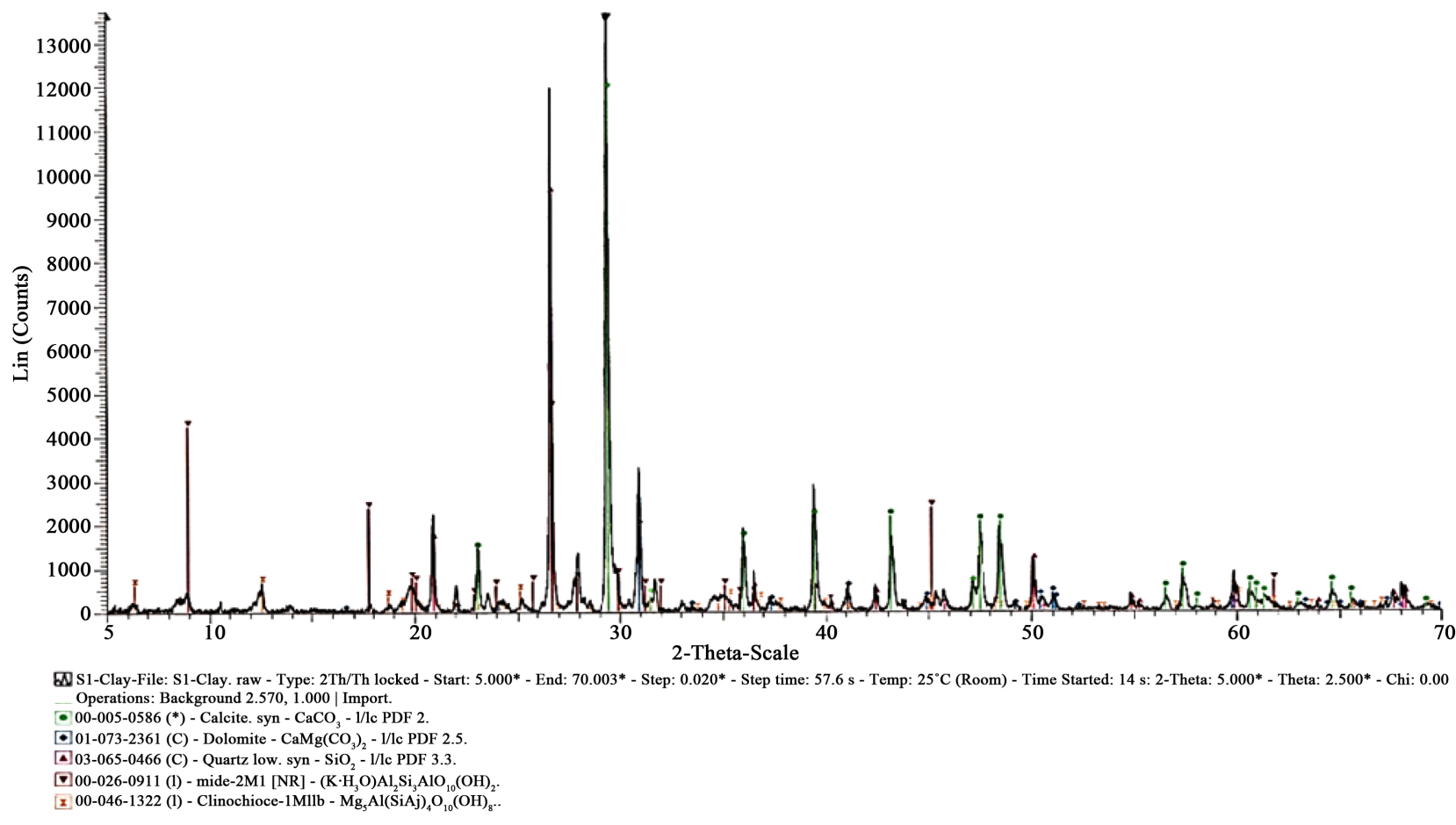

Figure 5. X-Ray diffraction chart for the sample No. S1 (Bulk sample).

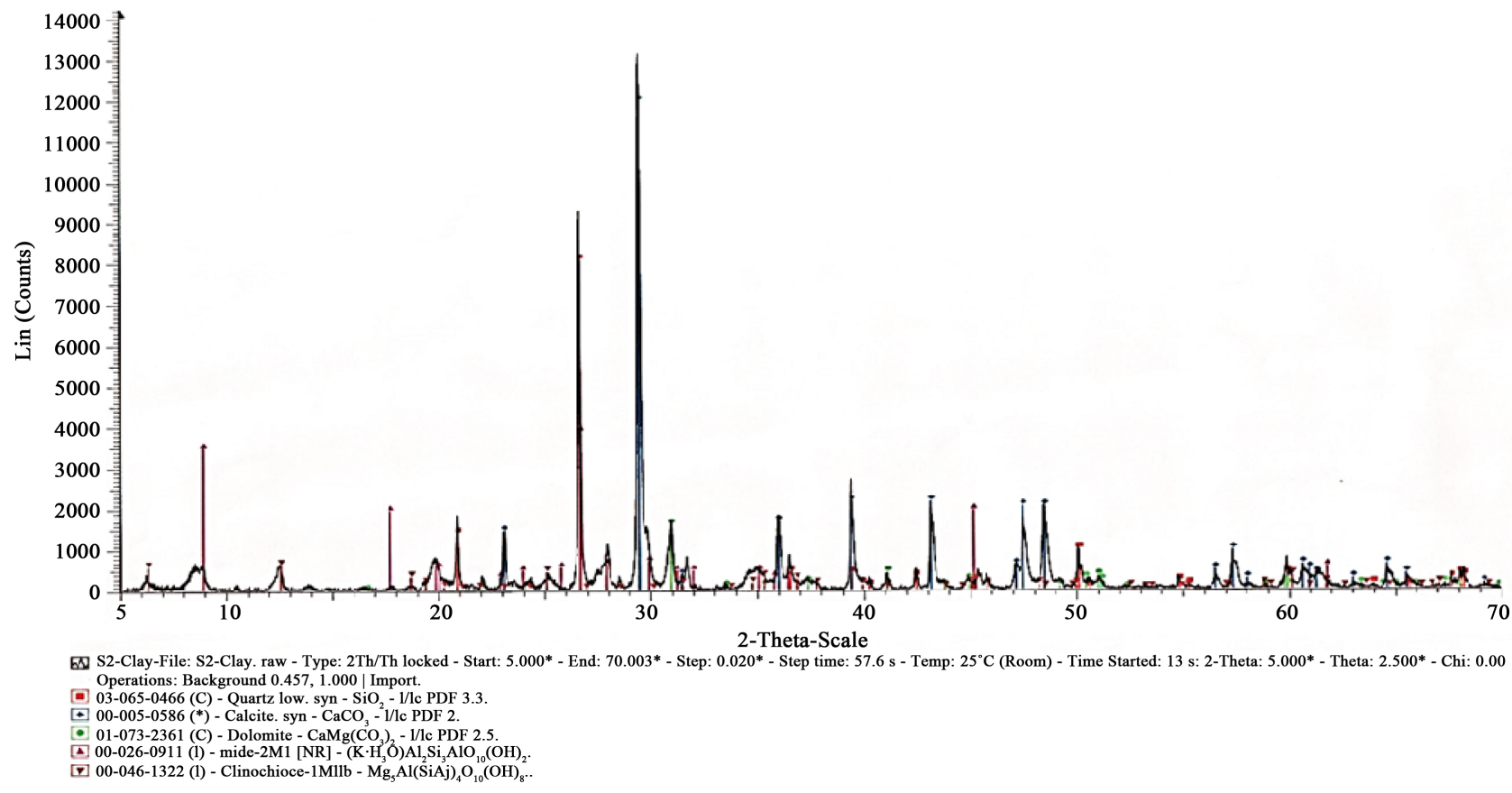

Figure 6. X-Ray diffraction chart for the Sample No. S2 (Bulk sample).

separately crushed and milled to fine particles. Power preparations and oriented samples in the air-dried and ethylene glycol solvated states using a SIEMENS D500 diffractometer (Fe-filtered $\mathrm{Cu}$ radiation) equipped with a Socabim DACO-MP recorder system. The system is controlled by the DiffracAT software. The scanning step and the counting time were $0.052 \mathrm{~h} \mathrm{CuK}$ an and $3 \mathrm{~s}$ 


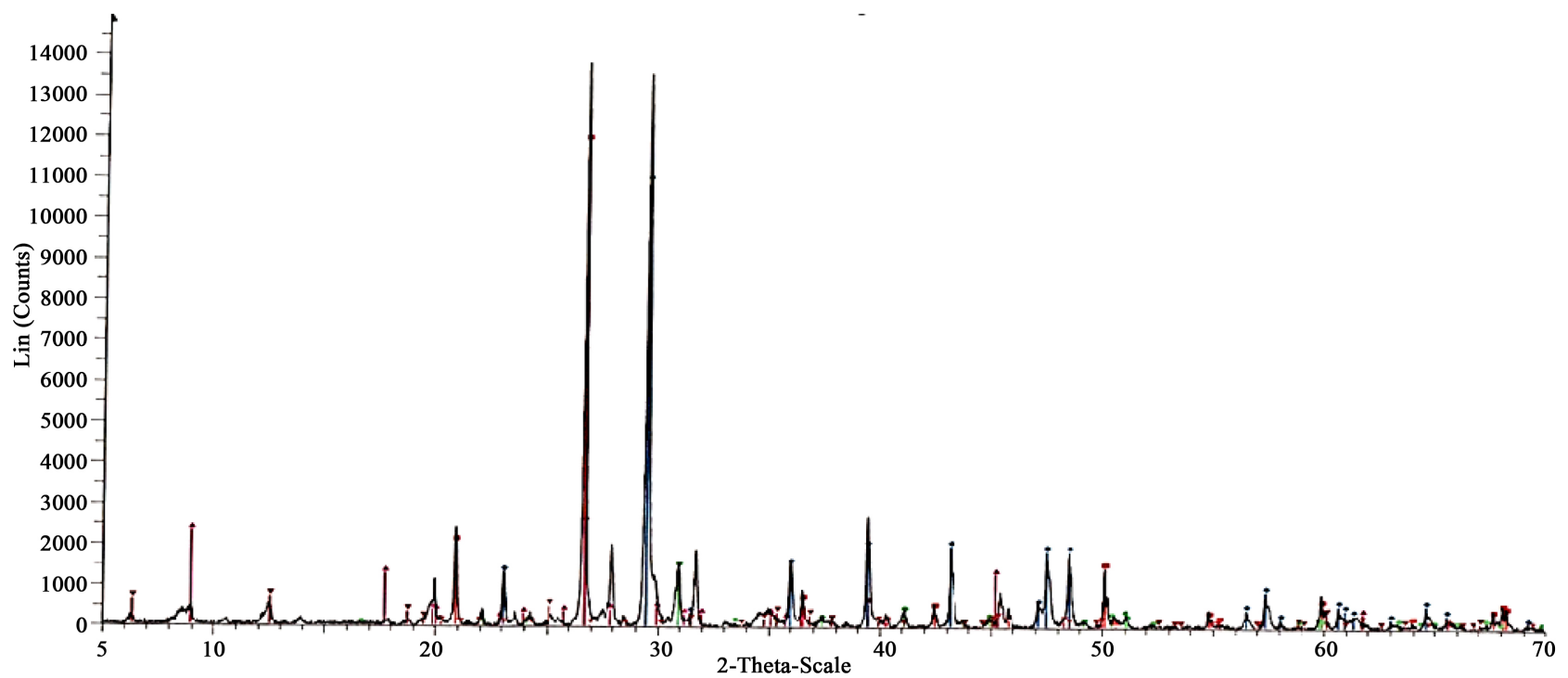

W S3-Clay-File: S3-Clay. raw - Type: $2 \mathrm{Th} / \mathrm{Th}$ locked - Start: 5.000* - End: $70.003^{*}$ - Step: $0.020^{*}$ - Step time: $57.6 \mathrm{~s}$ - Temp: $25^{\circ} \mathrm{C}$ (Room) - Time Started: $13 \mathrm{~s}: 2$-Theta: $5.000^{*}$ - Theta: $2.500^{*}$ - Chi: 0.00 Operations: Background 1.445, $1.000 \mid$ Import.
$03-065-0466$ (C) - Quartz low. syn - $\mathrm{SiO}_{2}-1 / \mathrm{lc}$ PDF 3.3. -00-005-0586 $\left({ }^{*}\right)$ - Calcite. syn $-\mathrm{CaCO}_{3}-1 / 1 \mathrm{lc}$ PDF 2.

- 01-073-2361 (C) - Dolomite - $\mathrm{CaMg}\left(\mathrm{CO}_{3}\right)_{2}$ - 1//c PDF 2.5

$\triangle 00-026-0911$ (l) - mide-2M1 [NR] - $\left(\mathrm{K} \cdot \mathrm{H}_{3} \mathrm{O}\right) \mathrm{Al}_{2} \mathrm{Si}_{3} \mathrm{AlO}_{10}(\mathrm{OH})_{2}$.

- 00-046-1322 (l) - Clinochioce-1Mllb - $\mathrm{Mg}_{5} \mathrm{Al}\left(\mathrm{SiAj}_{4} \mathrm{O}_{10}(\mathrm{OH})_{8}\right.$.

Figure 7. X-Ray diffraction chart for the Sample No. S3 (Bulk sample).

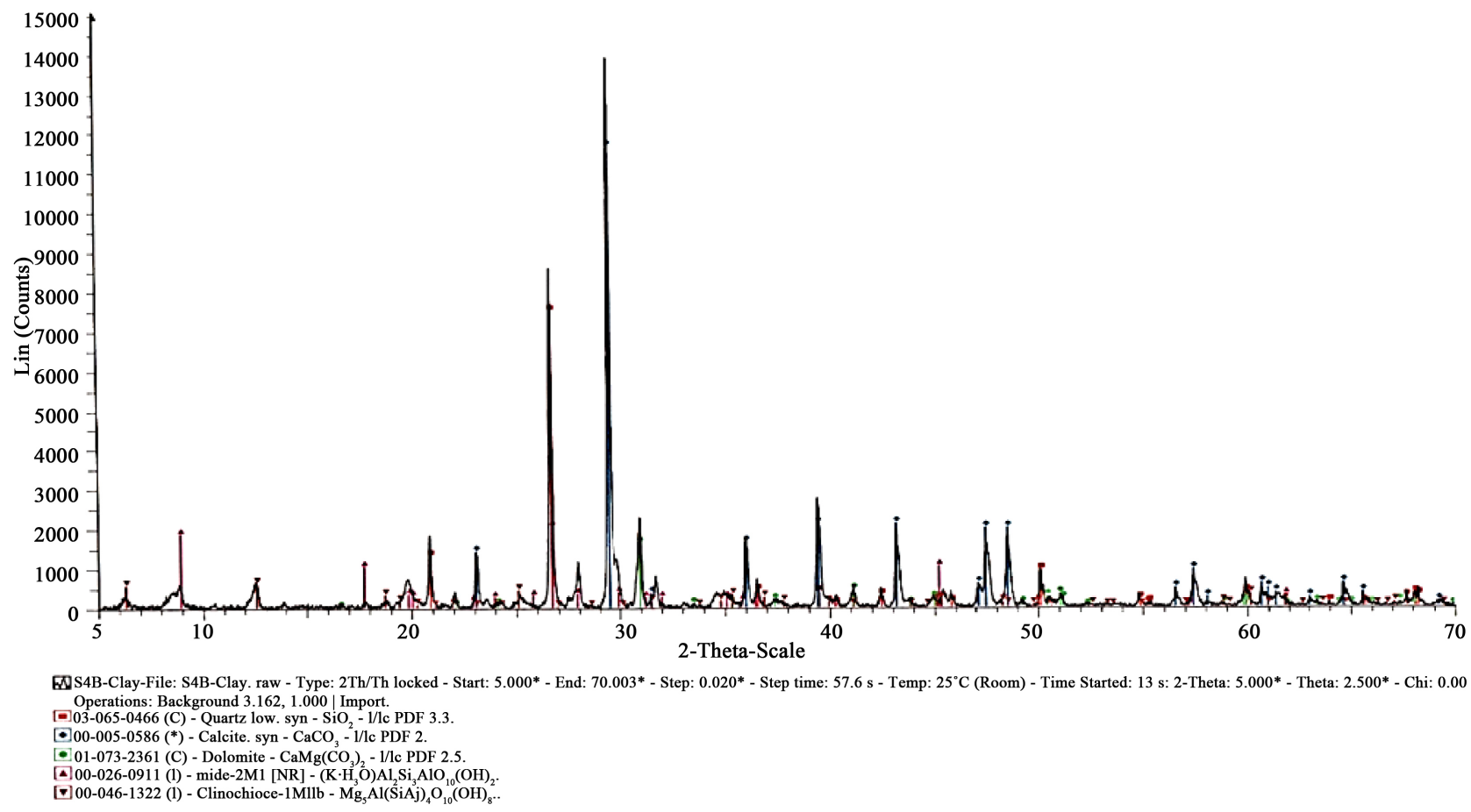

Figure 8. X-Ray diffraction chart for the Sample No. S4a (Bulk sample).

for the random powder samples and $0.0252 \mathrm{~h} \mathrm{CuK}$ an and $4 \mathrm{~s}$ for the oriented samples. CEC was determined by clay saturation with $\mathrm{Mg}_{2} \mathrm{p}$ (as $\mathrm{MgCl}$ ) and posterior displacement of $\mathrm{Mg}_{2} \mathrm{p}$ with $\mathrm{NH} \mathrm{p} 4$ (as $\left.\mathrm{CH}_{3} \mathrm{COONH}_{4}\right)$. Magnesium concentration was determined by atomic absorption spectroscopy. The background and peak-positions were identified and based on the peak positions and 


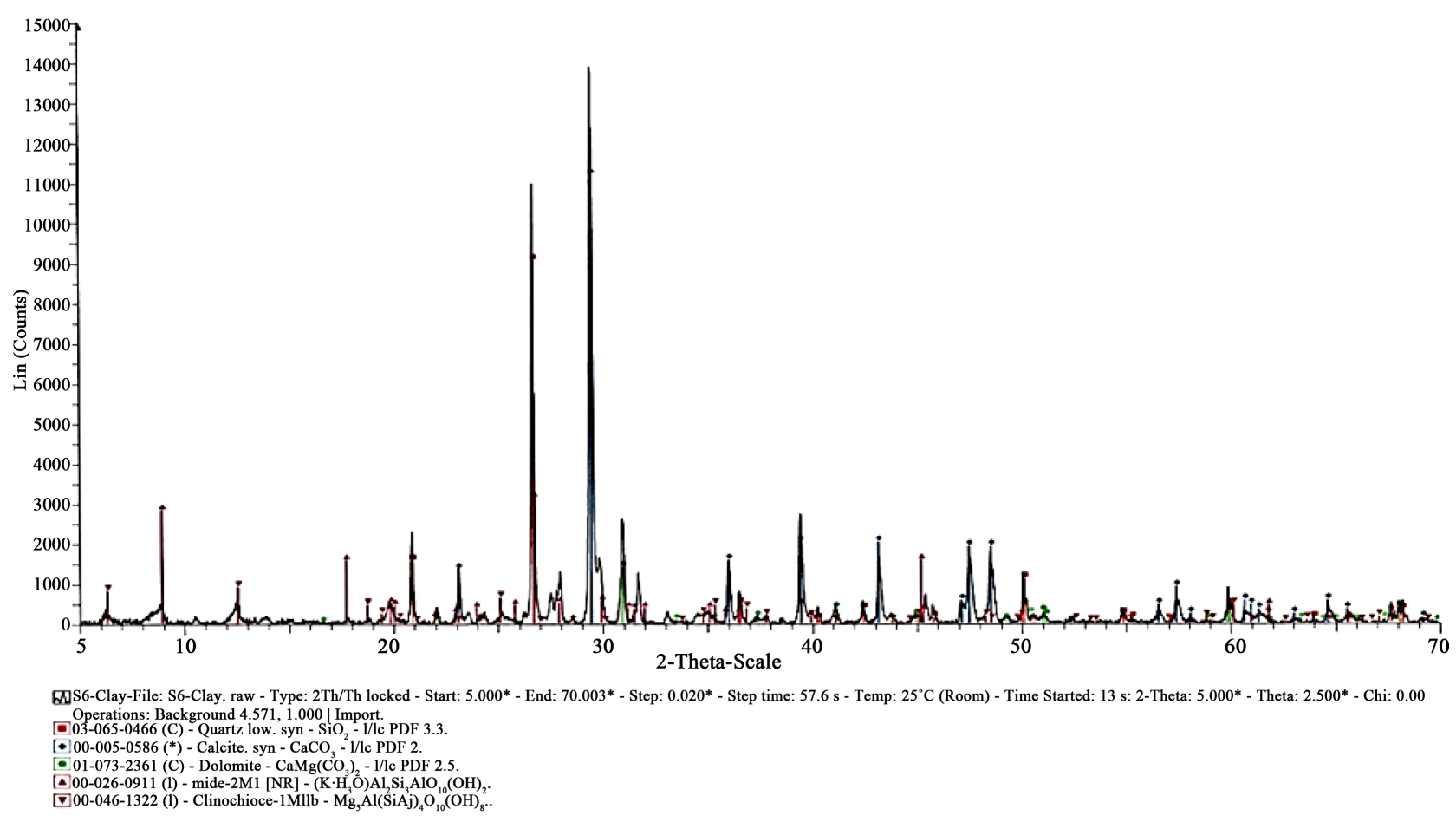

Figure 9. X-Ray diffraction chart for the sample No. S4b (Bulk sample).

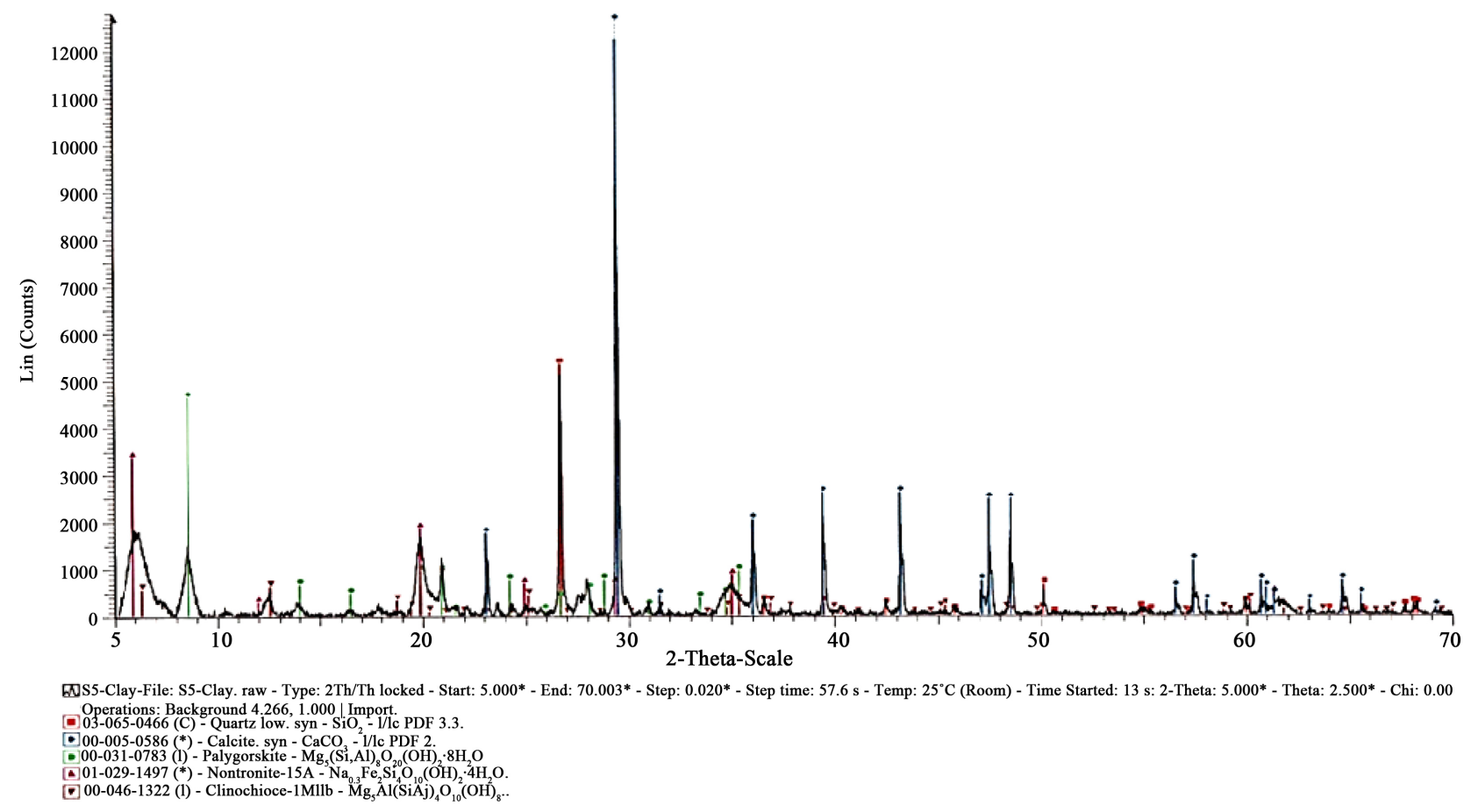

Figure 10. X-Ray diffraction chart for the Sample No. S5 (Bulk sample).

intensities, a search-match routine was performed. XRD was used to identify the mineral components in the samples and to determine, in part, the proportion of the clay minerals present. Randomly mounted material was scanned to determine the non-clay mineral component of the sediments, with mineral identification 


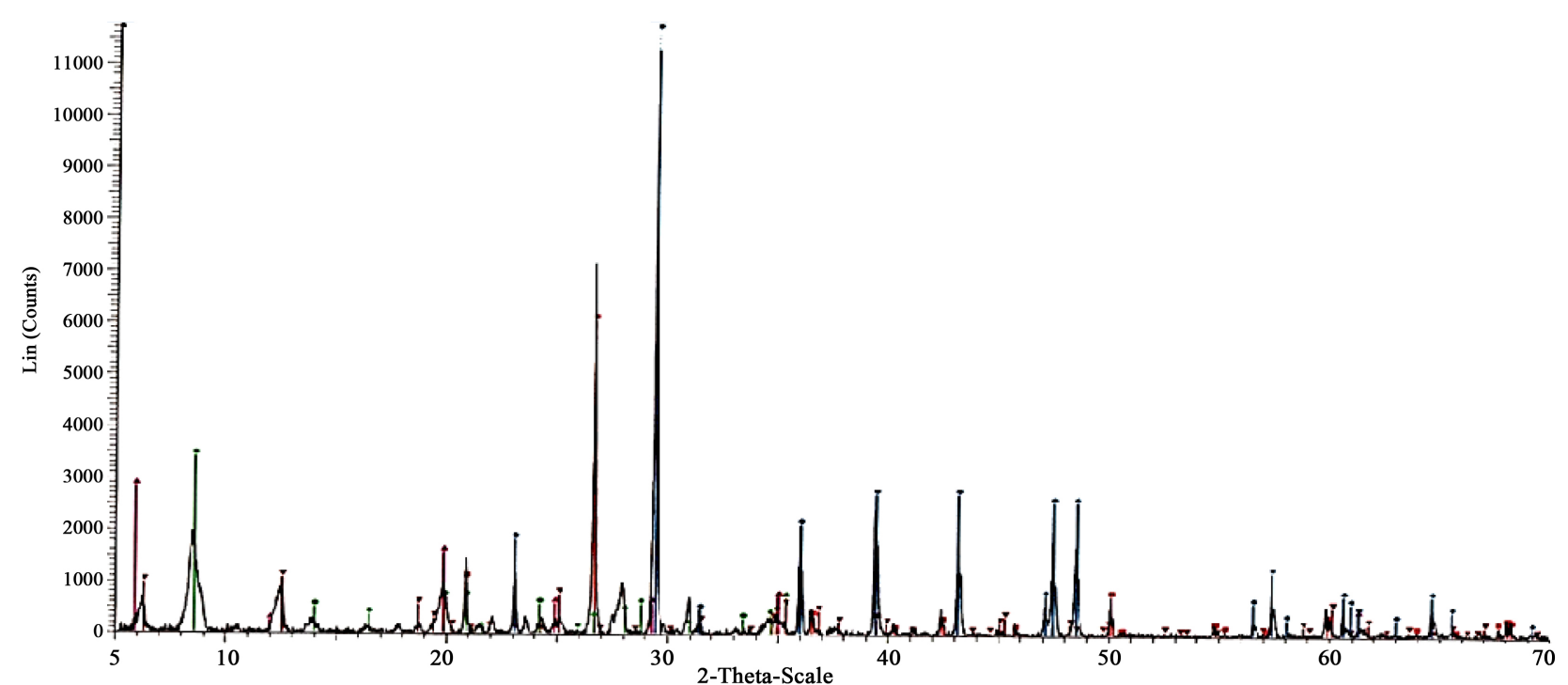

601 S7-Clay-File: S7-Clay. raw - Type: $2 \mathrm{Th} / \mathrm{Th}$ locked - Start: $5.000^{*}$ - End: $70.003^{*}$ - Step: $0.020^{*}$ - Step time: $57.6 \mathrm{~s}$ - Temp: $25^{\circ} \mathrm{C}$ (Room) - Time Started: $13 \mathrm{~s}: 2$-Theta: $5.000^{*}$ - Theta: $2.500^{*}$ - Chi: 0.00 Operations: Background 17.783, $1.000 \mid$ Import.
[D $03-065-0466$ (C) - Quartz low. syn $-\mathrm{SiO}_{2}-1 /$ lc PDF 3.3

- 00-005-0586 (*) - Calcite. syn - $\mathrm{CaCO}_{3}-1 / \mathrm{lc}$ PDF 2 .

- $00-031-0783(\mathrm{l})$ - Palygorskite - $\mathrm{Mg}_{5}\left(\mathrm{Si}_{1} \mathrm{Al}_{8} \mathrm{O}_{20}(\mathrm{OH})_{2} \cdot 8 \mathrm{H}_{2} \mathrm{O}\right.$

- 00-046-1322 (l) - Clinochioce-1Mllb - $\mathrm{Mg}_{\mathrm{A}} \mathrm{Al}(\mathrm{SiAj})_{4} \mathrm{O}_{20}(\mathrm{OH})_{3}$

Figure 11. X-Ray diffraction chart for the sample No. S6 (Bulk sample).

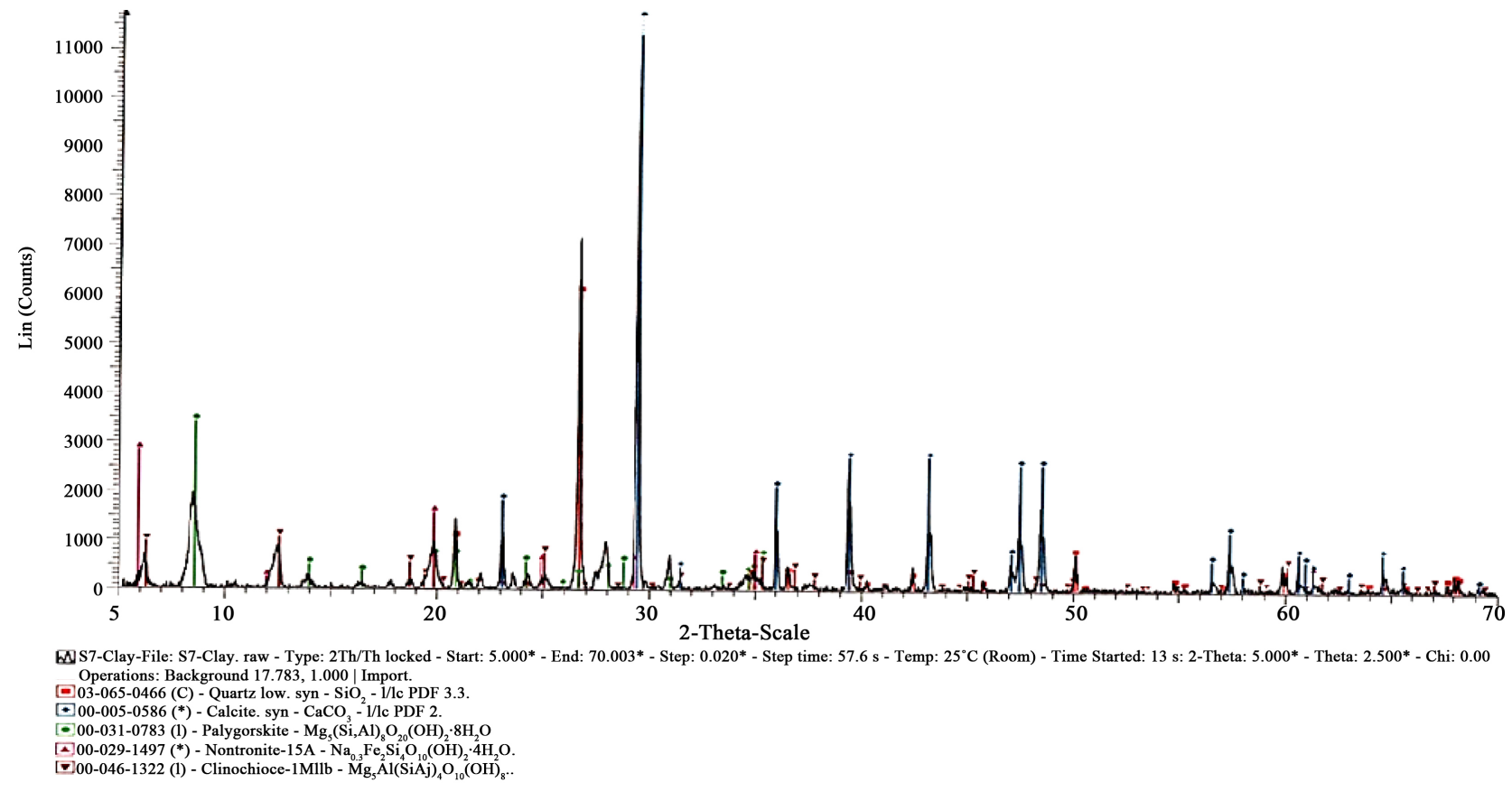

Figure 12. X-Ray diffraction chart for the sample No. S7 (Bulk sample).

being made against reference standard diffractograms. Clay mineral identification was made using samples sediment onto glass slides to maximize the diffraction peaks used to characterize these components ( $\{001\}$ and $\{002\}$ lines).

The identification of the clay minerals followed the methodology designed by [59]. This involved comparison of the X-ray patterns for sediments treated with 
1) ethylene glycol, 2) potassium chloride and 3) heat to $200^{\circ} \mathrm{C}, 450^{\circ} \mathrm{C}$ and $650^{\circ} \mathrm{C}$. Four main clay minerals were observed (see Figures 5-12)). Illite was identified by diffraction maxima at 10,5 and $3.3 \AA$, all of which remain unaffected by glycolation. Smectite was identified by broad diffraction maxima around $14 \AA$ that shifted to a broad peak around 16 to $18 \AA$ on glycolation and to $10 \AA$ on heating to $450^{\circ} \mathrm{C}$. Chlorite was identified by diffraction maxima at 14,7 and $3.5 \AA$ and remained unaffected by glycolation or potassium chloride treatments, although the peaks decreased in intensity on heating to $650^{\circ} \mathrm{C}$. Kaolinite was identified using the major diffraction lines but straightforward identification could not be made using the $\{001\}$ line due to partial masking of the $7 \AA$ basal peak: several other higher order peaks were used for the identification, in most cases, although for some samples, low chlorite levels meant that a clearer identification could be made. The percentage of the clay minerals was determined by comparing the peak areas of the $\{001\}$ diffraction patterns on glycolation. For this, the peak areas were weighted on a basis of 1:2:4 for smectite, illite and chlorite plus kaolinite [60]. Chlorite and kaolinite could not be distinguished because of the closeness of the $7 \AA$ peak and semi-quantitative separation of these components involved chemical-leaching methodologies described later in the paper. In addition, there were sometimes small and broad peaks in the region of 11 to $13 \AA$ spacing, which "smeared out" even more on glycolation. These presumably represented mixed-layer clays, but details of the mineralogy could not be assessed due to the small size of the peaks and the presence of other clay mineral peaks.

\subsection{Materials and Methods for Ceramic Preparation}

Based on [61], who mentioned that, the researchers undertaking this work are primarily Fine Artists, Designers and Crafts persons (practitioners) and as such have sought methodologies which reflect their discipline-specific expertise. This has led to the use of the terms "practice-based" or "practice-led" research. This reflects a change in emphasis in research from research about the Visual Arts and artists, designers, crafts persons. These shifts in research frameworks are also taking place in other disciplines, and are symptomatic of a global reappraisal of the nature of knowledge and communication.

This research will depend on practice based research in using and testing clays, understanding the validity of the clays to be used in the forming pottery. Also, identifying the percentage of the amount of the clay and Pseudo matrix within each amount of clay.

In the beginning of this research some samples were taken from different areas in Subiyah, located in north of Kuwait and near to Bobyan Island. Seven samples were taken from different places. The practice based in this research divided into three applications for clay mineralogy, these areas as the following:

\subsubsection{First Application: Weighting the Clay Sediments}

In this application, researchers were taken a sample amount of 100 gr. sediments 
from every station, put it in a sieve with mish less than $63 \mu$ (clay size), then washed it with normal tape water, to separate calcareous materials and dust (Figure 13). Finally, authors measured the weight of the rest pure clay sediments to record the best area of clay samples (Table 1).

\subsubsection{Second Application: Using the Clay in the Mould Test}

In this test, each sample was tested inside press mould clay of cup form to see the practice result of each clay after the firing under $1031^{\circ} \mathrm{C}$ Figure 13 .

\subsubsection{Third Application: Throwing Clay Test}

In this experiment, each sample was tested by throwing experiment technique, using the electronic wheel to see the forming of clay in making bowls and cups

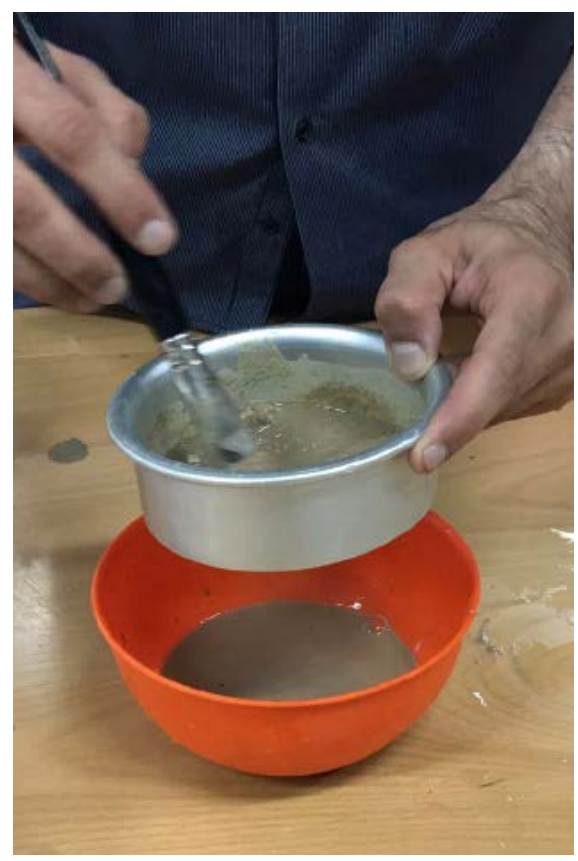

Figure 13. Clay preparation using strainer local clay body preparation and clay throwing process at Subah Al Ahmad Centre for Giftedness and Creativity.

Table 1. Weight of sands and calcareous sediments (Non-clay Sediments) in studied sample.

\begin{tabular}{cc}
\hline Sample No. & Weight of Non—Clay Deposits by Gram \\
\hline 1 & 32.5 \\
2 & 17.1 \\
3 & 48.4 \\
4 & 40.8 \\
5 & 9.7 \\
6 & 50.6 \\
7 & 6.7 \\
\hline
\end{tabular}


into the pottery product and observing the results after the firing in the kiln $1031^{\circ} \mathrm{C}$ (see Figures $13-20$ ).

It has been weighting the sands and grains in each sample of clays and the results shows in Table 1.

\section{Results and Discussion}

\subsection{Mineralogical Composition}

Samples; S1, S2, S3, S4A, S4B and S6 show low quartz, Calcite (Caco3), Dolomite,

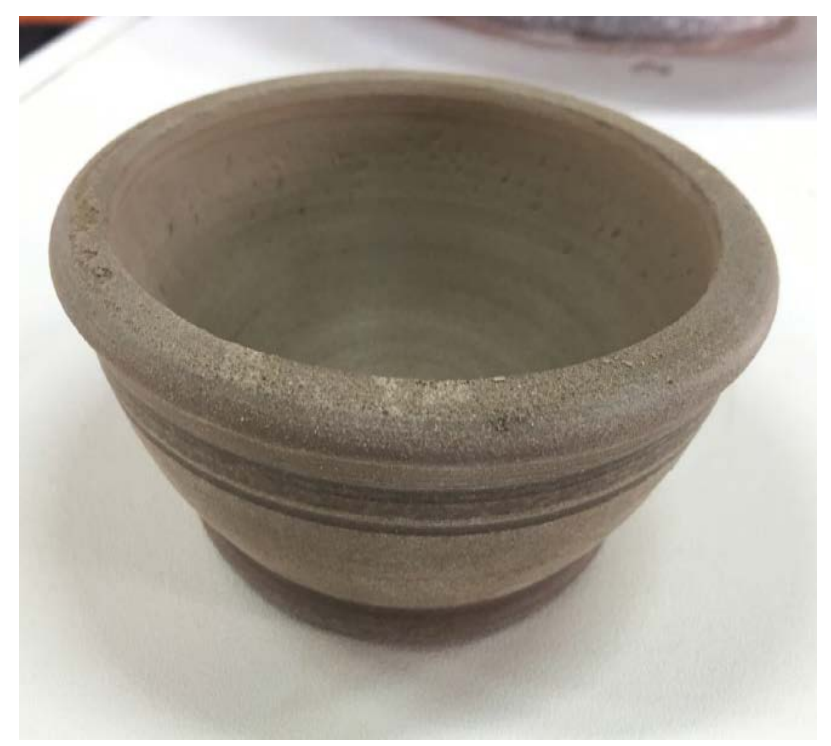

Figure 14. Local clay body preparation and clay throwing process at Subah Al Ahmad centre for giftedness and creativity, sample No. 1 .

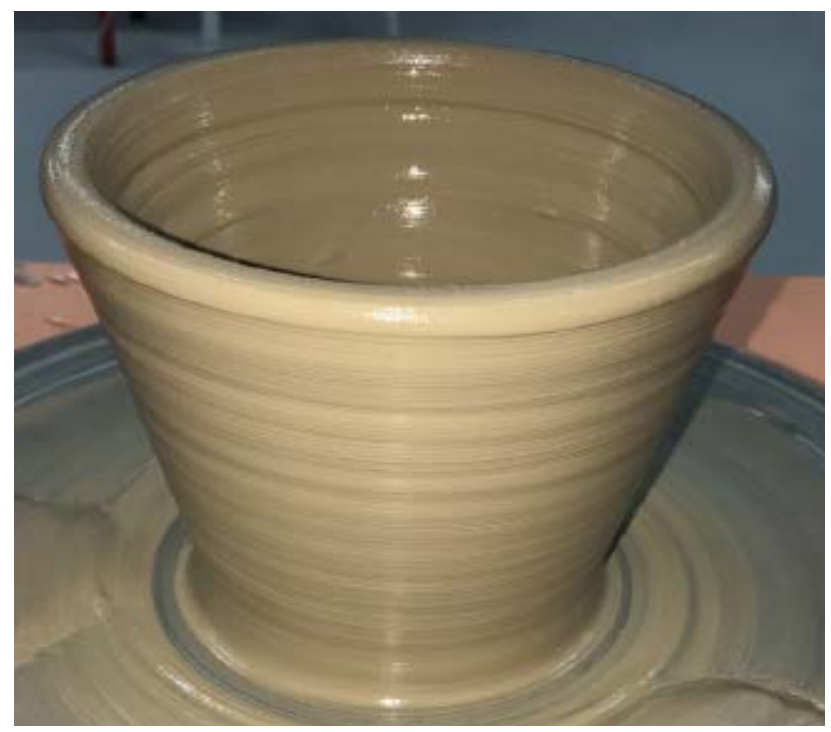

Figure 15. Local clay body preparation and clay throwing process at Subah Al Ahmad centre for giftedness and creativity, sample No 2 . 


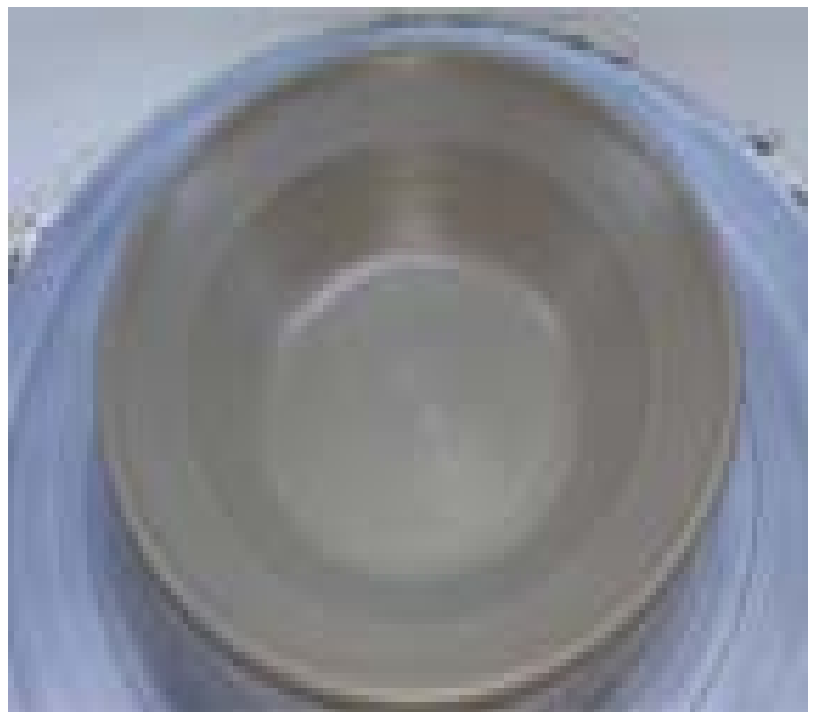

Figure 16. Local clay body preparation and clay throwing process at Subah Al Ahmad centre for giftedness and creativity, sample No. 3 .

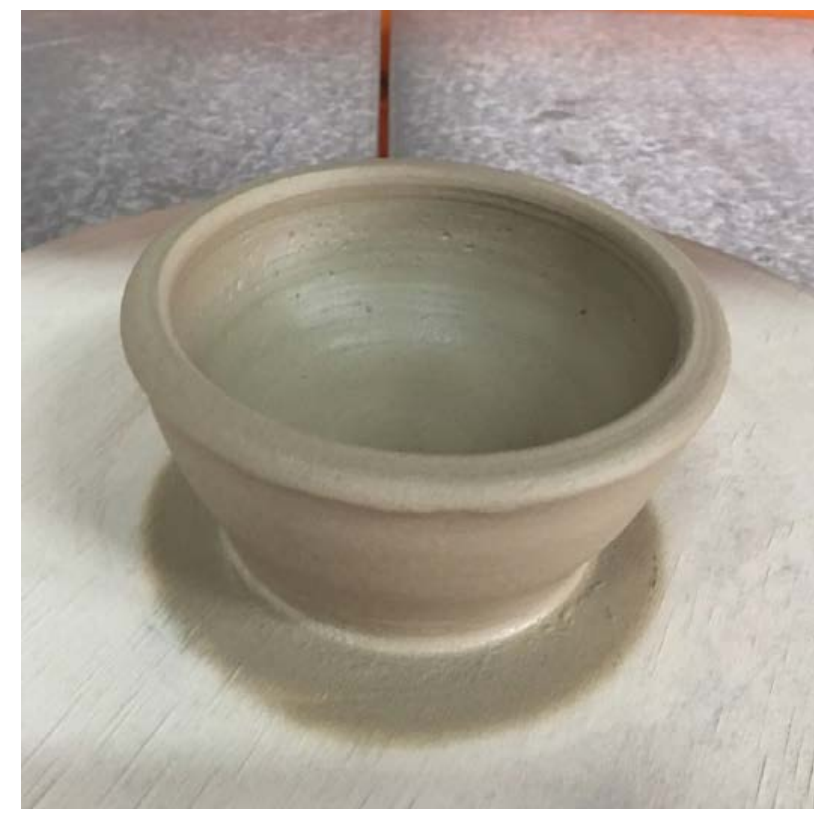

Figure 17. Local clay body preparation and clay throwing process at Subah Al Ahmad centre for giftedness and creativity, sample No 4 .

Illite and Clinochlore. Whereas; Quartz, Calcite Dolomite, Palygorskite, Nontronite and Clinochlore were recorded at S5 and S7 (see Figures 5-12). Table 1, shows the weight of non-clay sediments, it could notice the most purity of clay in sample 7 , then sample 5 , and finally sample 2 gradually.

\subsection{Result of the Applying Samples on the Wheel}

In such step applying the wheel for the clay samples. This stage is the most 


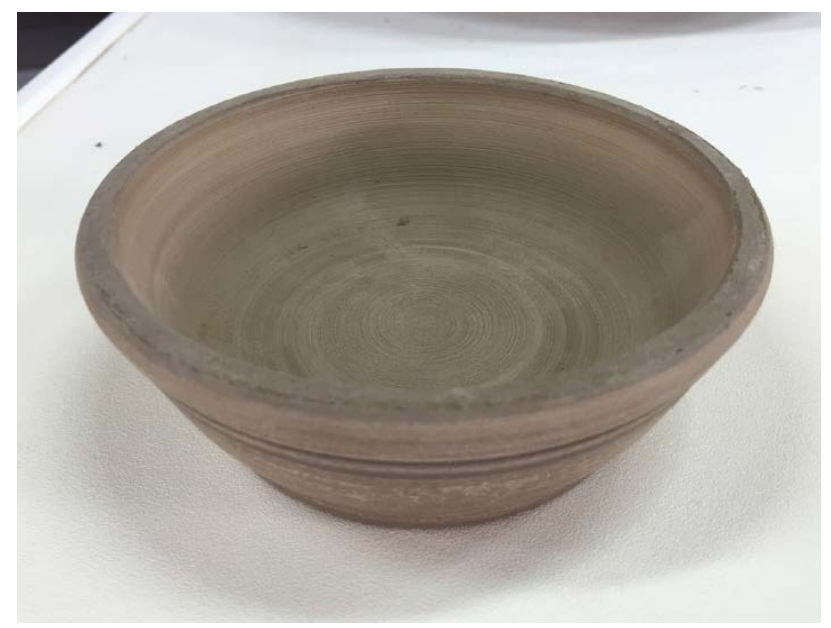

Figure 18. Local clay body preparation and clay throwing process at Subah $\mathrm{Al}$ Ahmad centre for giftedness and creativity, sample No. 5 .

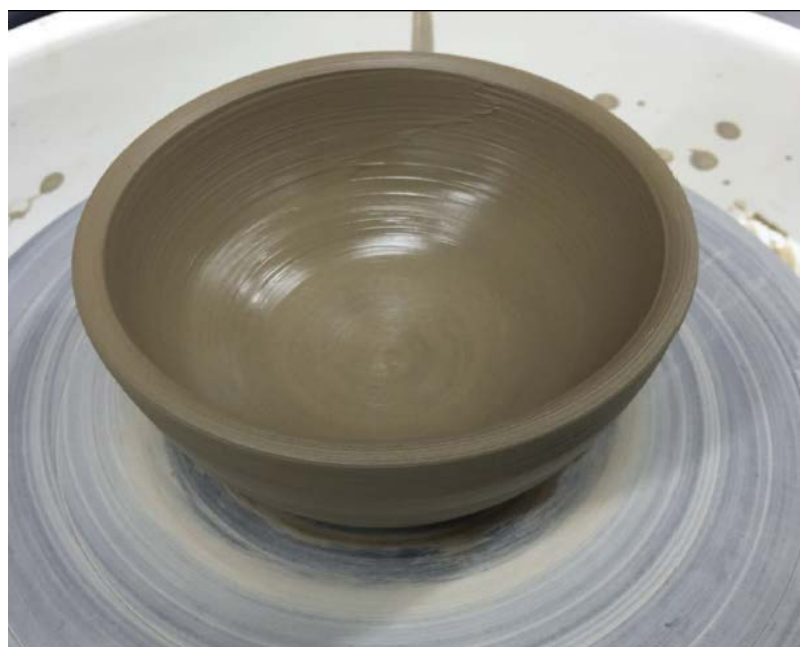

Figure 19. Local clay body preparation and clay throwing process at Subah Al Ahmad centre for giftedness and creativity, sample No. 6 .

important one for the potters and Ceramists designer, to design and make a cups and bowls or vases. In the beginning of this step, the clay of each sample purified from grains Table 2, stones and pseudo-matrix by using strainer size $100 \mathrm{ml}$, then preparing the clays to be use for throwing (see Figures 14-28). Throwing on the wheel start with centering the clay, then opening, expanding and rise the clay up, then forming the bowl or the cup. After that trimming the back side of the shape to get the final form. All these processes done for all samples of the Subiyah clay. In the final step cups and bowls were fired in the electrical kiln under temperature 1031 Celsius (see the following picture steps).

\subsection{Results of Applying Clay Samples on the Press Mould}

In this stage of the research, a mould from plaster selected with a form of cup 


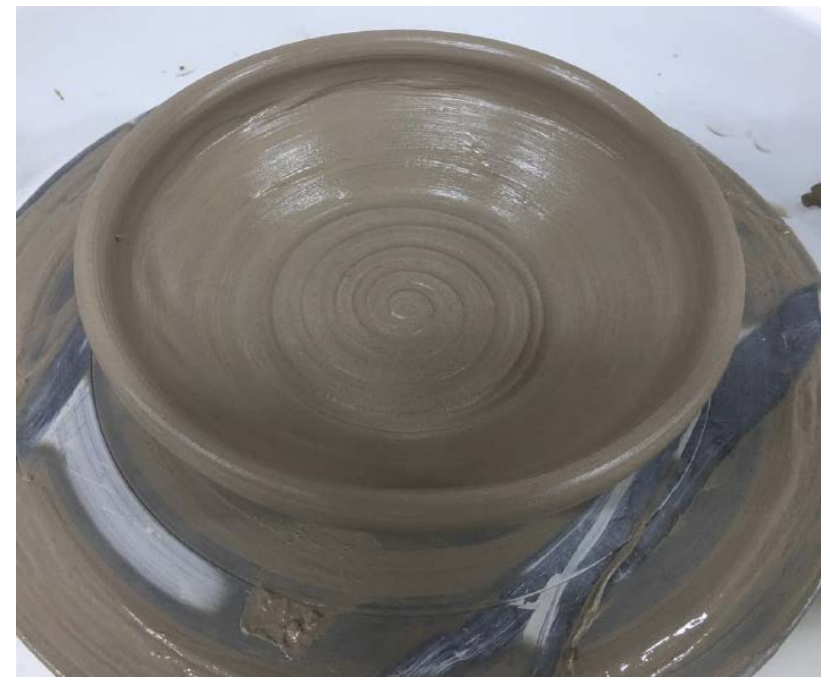

Figure 20. Local clay body preparation and clay throwing process at Subah Al Ahmad centre for giftedness and creativity, sample No. 7 .

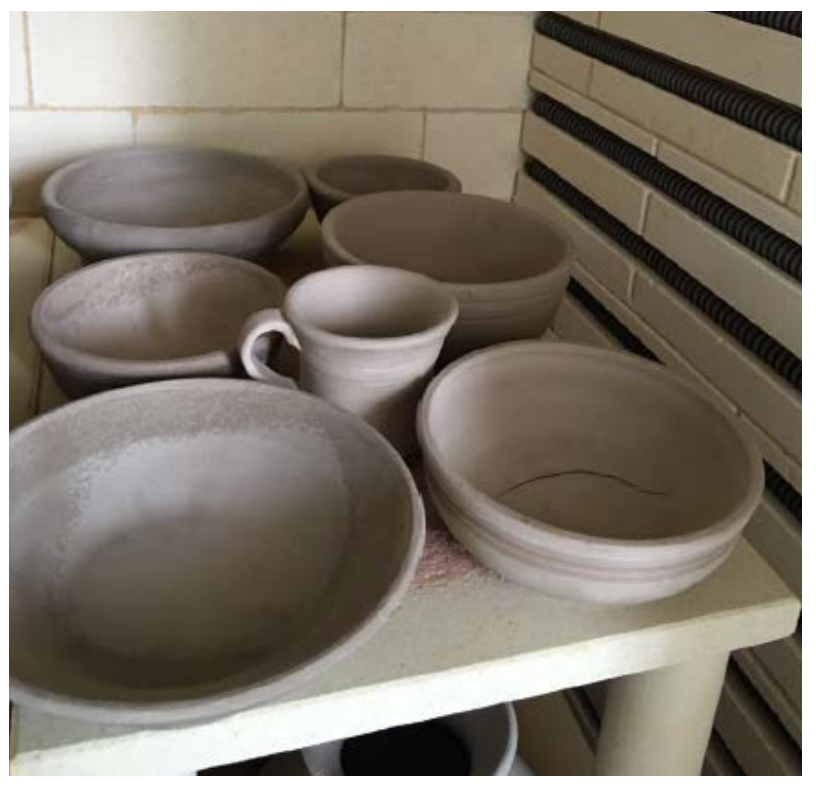

Figure 21. Firing all samples under temperature of $1031 \mathrm{Cel}-$ sius.

Table 2. Other clays samples were prepared but without purify from grains, applied to plaster mold and pressing the clay inside mould. In the final stage of this experiment clays were dried after the cup shape then fires it in the kiln under temperature 1031 Celsius Figures 23-28 (see the following steps).

From this experiment of applying samples inside the mold, the best clay can be seen in sample (6), this because the clay body kept the same form of the mould cup. Also, it gave a strong body pottery after firing. The next best sample was sample number (7) then sample (2) this because of firming of the silicate and less grains. Finally, came sample (5), but this sample was bind during 


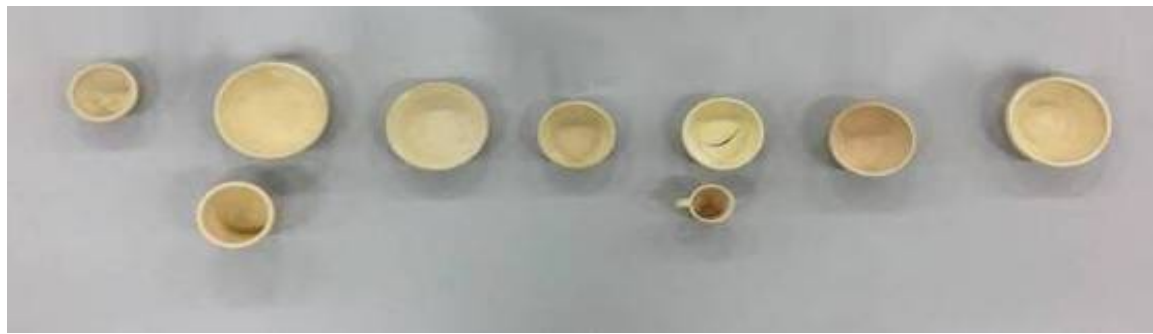

Figure 22. Display of the fired pottery wares of the studied clay samples at Subah $\mathrm{Al} \mathrm{Ah-}$ mad centre for giftedness and creativity-ceramic workshop.

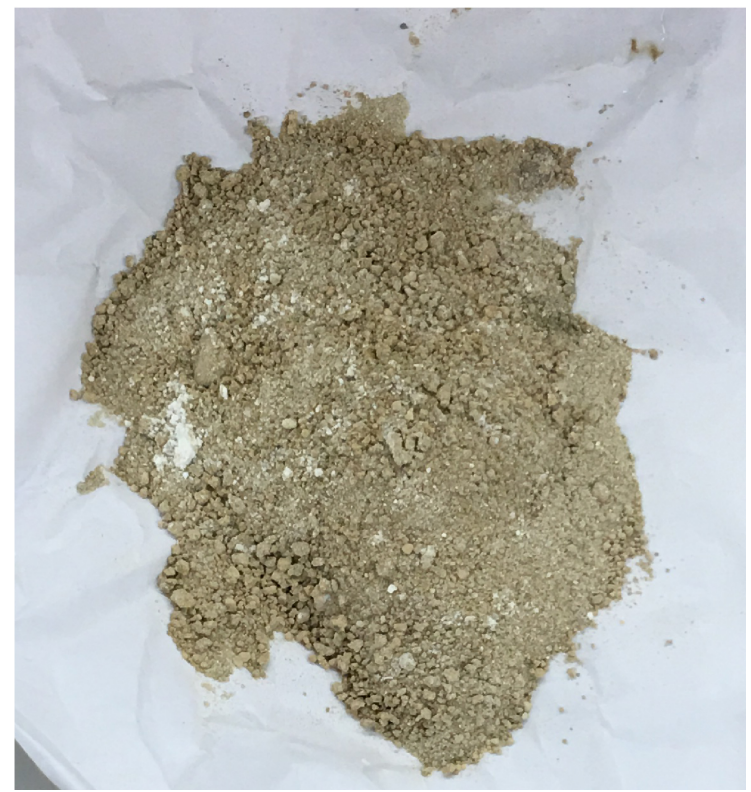

Figure 23. Crashed and demolished clay sample No. S1 in the mould after firing.

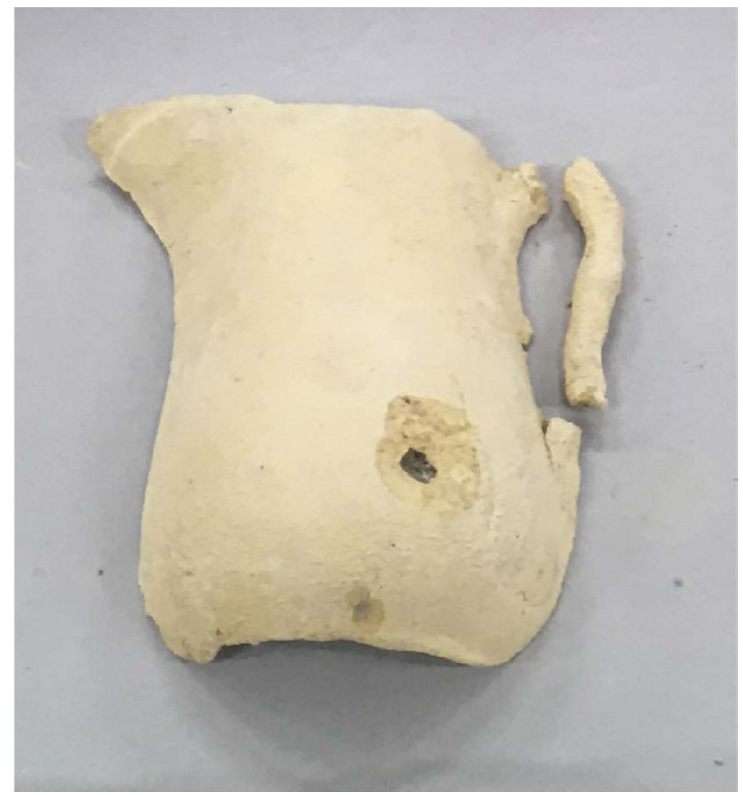

Figure 24. S2 sample, showed body of the pottery firm. 


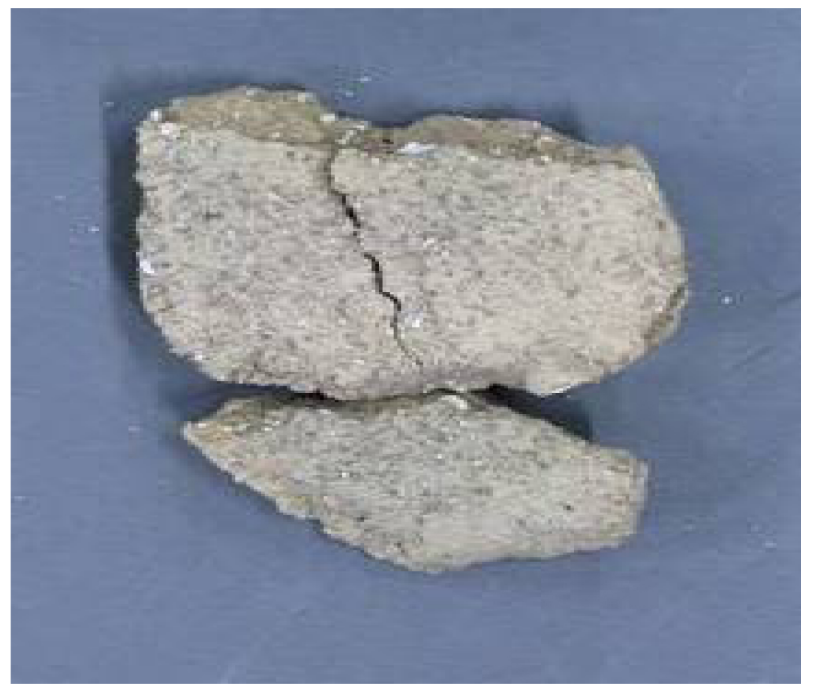

Figure 25. S3 sample showed, sands and gravels as seen in the body of the pottery.

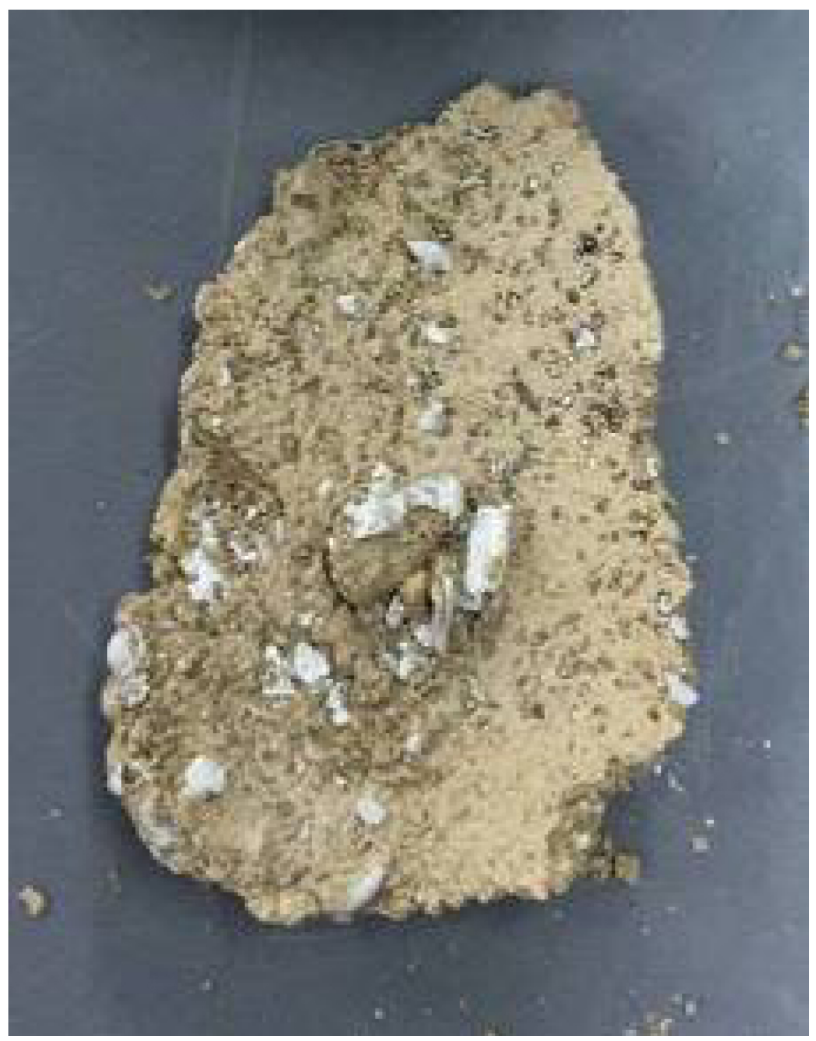

Figure 26. S4 sample showing demolishing and crashing after firing.

shrinking and change the pottery form of the cup. Samples (1), (3) and (4) are not suitable for clay forming in the mould. This because of containing more sands and grains or stones or it has a less silicate. In general, some clays could add more materials towards occurring or improving the body of the clay samples. 

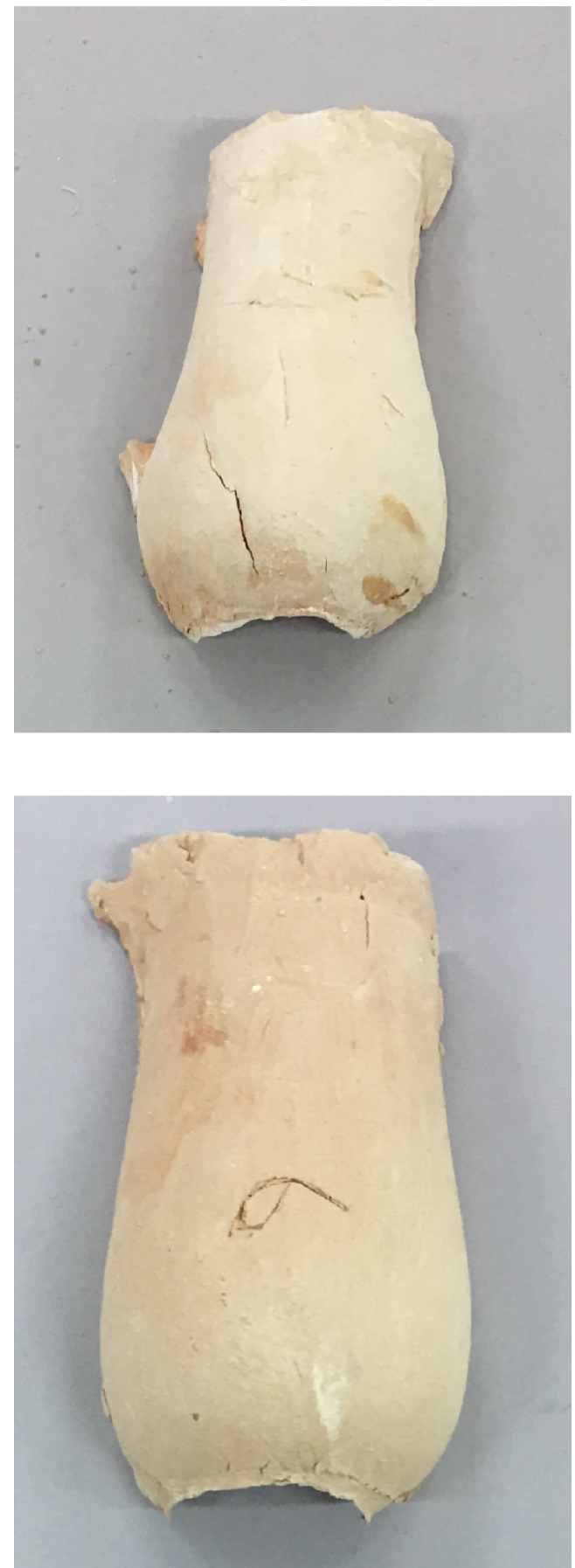

Figure 27. S6 sample, showing clay compaction after firing and notice the shrinking caused body bindi.

\section{Ecology of the Area}

The study area is located North West Subiyah, at the far Northeast Kuwait. The ecology background of the area shows: poor vegetation cover controlled primarily by rain flow, and by land form. Darning lines and sandy basins are favoured sites for plant growth (see Figure 29 \& Figure 30). In Subiyah Four ecosystems 


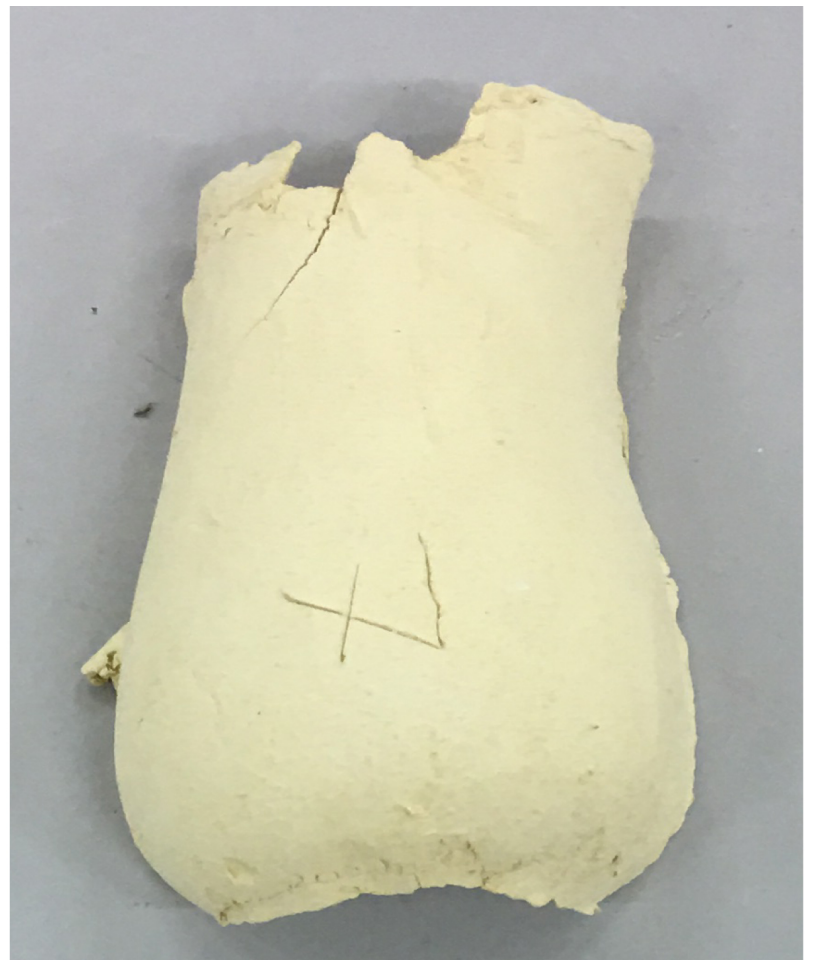

Figure 28. S7 sample after firing.

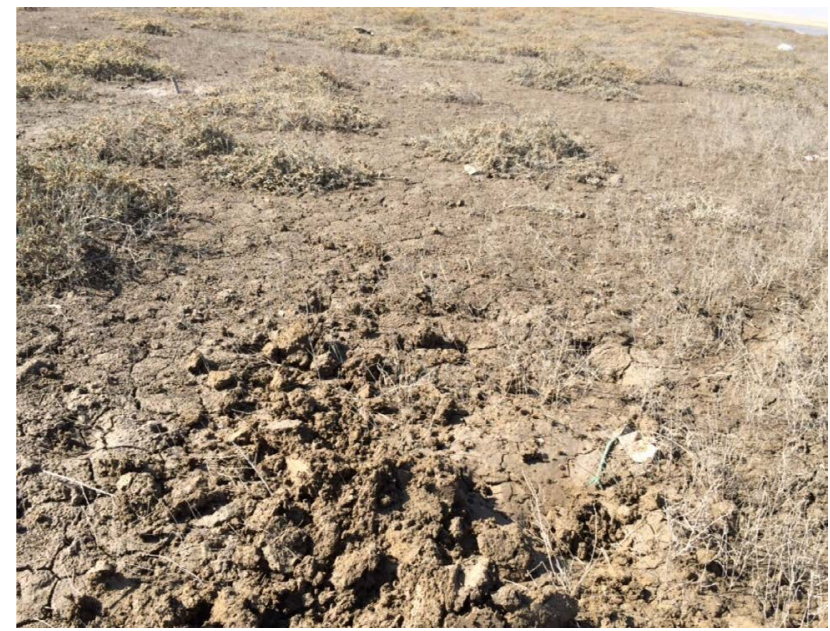

Figure 29. Clay mineral deposition at station No. S6.

based on varieties in the habitats, land form and soil characteristics and floristics composition could be formed. These ecosystems are: Sand dunes ecosystem; 2-The salt march and saline depressions; 3-The desert plain ecosystem; 4-The desert plateau ecosystem [62]. The authors did the study on clay minerals on Subiyah area (Figure 1). Since the study area in the far and northeast desert of Kuwait (Subiyah) close to the beach, no urbanization has been developed and no human activities are noticeable in the desert; such factors reduce the source of pollution. Although no hydrocarbon analyses made for the clay samples, but it seems, that clay minerals in the study area are pure. North east Subiyah might 


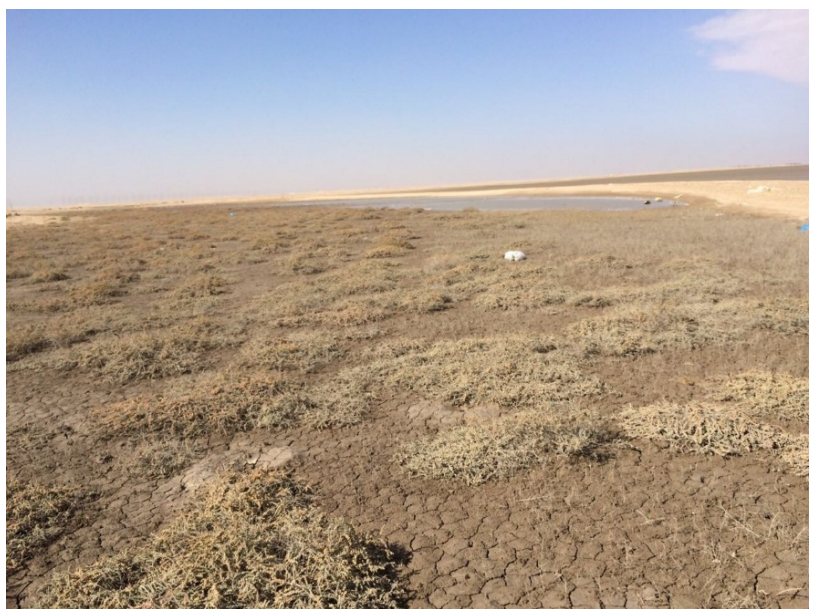

Figure 30. Poor vegetation cover near North east Subiyah with no urbanization. Development in the area.

Table 2. Clay analysis for art craft industry.

\begin{tabular}{|c|c|c|c|}
\hline $\begin{array}{l}\text { Sample } \\
\text { number }\end{array}$ & $\begin{array}{l}\text { Clay, flexibility } \\
\text { characteristics and the } \\
\text { forming on the wheel }\end{array}$ & Clay in the air & $\begin{array}{l}\text { Clay after firing under } \\
\text { the } 1031 \text { degree }\end{array}$ \\
\hline 1 & $\begin{array}{l}\text { Suitable for throwing use, } \\
\text { soft, but it has a smell }\end{array}$ & $\begin{array}{l}\text { does not change the } \\
\text { shape form }\end{array}$ & Suitable for art craft \\
\hline 2 & $\begin{array}{l}\text { Suitable for throwing } \\
\text { but it is so soft }\end{array}$ & $\begin{array}{l}\text { The clay does not show a } \\
\text { change the shape form }\end{array}$ & $\begin{array}{l}\text { Suitable but sometimes } \\
\text { showed cracks at } \\
\text { the surface }\end{array}$ \\
\hline 3 & $\begin{array}{l}\text { Suitable and easy forming } \\
\text { and has a big of flexibility }\end{array}$ & $\begin{array}{l}\text { The clay does not change } \\
\text { the shape form }\end{array}$ & Suitable after firing \\
\hline 4 & Suitable and easy forming. & $\begin{array}{l}\text { The clay didn't change } \\
\text { the shape form }\end{array}$ & Suitable after the fire \\
\hline 5 & $\begin{array}{l}\text { Suitable and easy } \\
\text { forming and building. }\end{array}$ & $\begin{array}{l}\text { Not suitable and it caused } \\
\text { cracked within the body } \\
\text { surface after drying }\end{array}$ & $\begin{array}{l}\text { The form changed and the } \\
\text { surface bend and it caused } \\
\text { cracked with the body of } \\
\text { the pottery }\end{array}$ \\
\hline 6 & $\begin{array}{l}\text { Suitable and easy forming } \\
\text { and has a big flexibility. }\end{array}$ & $\begin{array}{l}\text { Suitable and the form } \\
\text { didn't change its design. }\end{array}$ & Suitable after firing \\
\hline 7 & $\begin{array}{l}\text { Suitable and easy forming } \\
\text { and has big flexibility }\end{array}$ & $\begin{array}{l}\text { Suitable and the form } \\
\text { didn't change its design }\end{array}$ & Suitable after firing \\
\hline
\end{tabular}

resemble suitable location for clay industry, taking in consideration other positive factors for clay minerals (Figure 22)

\section{Discussions and Conclusion}

Based on XRD analysis and field observations, samples were showed consistency in the revelation of the quantities of different constituents of the clays. X-ray diffraction study shows the presence of quartz, calcite, Dolomite, Illite, Clinochlore, Palygorskite, and Nontronite, as major phases. The clays after purification ex- 
hibited the potential for application in the production of refractories. Authors concluded the present of Palygorskite mineral in S5 and S7 samples are detrital, transported mostly by NW winds comes from Iraq, and arid climate. The clay deposits studied correspond to highly plastic clays with low contents of quartz. All studied samples were considerably plastic raw materials explaining their excellent aptitude for pressing except sample no. S3, which show less plasticity due to highly carbonate and gypsum content. The sample mineralogy indicates quartz as a primary mineral, followed by plagioclase. Illite, Clinochlore, Palygorskite, Nontronite were the main clay minerals in the raw material samples. From the industrial application for clays, originally, compositionally, they are an excellent raw material for the formulation of low porosity ceramic stoneware [15] [63]. The presence of Illite in all studied samples was influenced by burial diagenesis leads to alteration of Smectite to Illite [see [64] [65] [66]. The results obtained from our tests lead us to envisage new research programmes in Subiyah area focused on testing these and assessing the effective possibility of using ceramic raw materials in the local ceramic industry. Based on the results of this study the following conclusions have been reached out; the plasticity values show samples no. (S1, S4, S5, S6, S7) were medium plastic, samples no. (S2 and S3) are low plastic, clays with plasticity, permits it to be shaped or moulded when mixed with water, and have sufficient wet and air dried tensile strength to maintain their shape after forming. When subjected to rising temperature, the clay particles must fuse together (i.e., the plasticity values show that the sample no. (S2 and S3) had low plasticity range between $6.7-8.48$, these values allow to make shaped tiles. X-Ray diffraction shows that the samples with constitute clay minerals (Illite, Clinochlore, Palygorskite, and Nontronite) and non-clay minerals (quartz, calcite and Dolomite). The physical and mechanical properties that concern with the clay brick are; due to measure of physical and mechanical properties. Clay brick affected by low volume and linear shrinkage during both drying and firing with higher temperature at $1000^{\circ} \mathrm{C}$. The raw materials taken from Subbaya at Northern Kuwait are suitable for producing high quality clay brick. Subiyah clay is valid for use in artistic and production pottery. The most purify clay from grinds and stones were sample S7. The best sample that can be suitable for throwing clay in the wheel is sample (S1), (S3), (S4), (S6) and finally (S7). For press mould of clay samples, the best sample was (S7), (S2), and sample (S5) but with a little bit binding. In other hand the invalid samples were sample (1), (3), and sample (S4) which crashed after firing. In conclusion, sample (S7) was show a good behavior for mold, throwing and less grinding then (S2) sample and sample (S6) at last.

\section{Acknowledgements}

Authors thank Mrs. Eiman Morsy, she kindly improved the English of the manuscript. Also, authors thank Subah Al Ahmad Centre for Giftedness and Creativity-Ceramic Workshop for their cooperation and facilities assistant dur- 
ing this work and Kuwait Institute for Scientific Research (KISR) for qualitative $\mathrm{XRD}$ analysis.

\section{References}

[1] Jordán, M.M., Pardo, F., Sanfeliu, T. and Meseguer, S. (2014) Ceramic Behaviour of Some Clay Deposits from Guayas Province, Ecuador: Preliminary Study. Applied Clay Science, 101, 619-622. https://doi.org/10.1016/j.clay.2014.09.028

[2] Wilson, M.J., Wilson, L. and Patey, I. (2014) The Influence of Individual Clay Minerals on Formation Damage of Reservoir. Sandstones: A Critical Review with Some New Insights. James Hutton Institute, Aberdeen, and Corex (UK) Ltd., Howe Moss Drive, Aberdeen.

[3] Daskshama, V., Mohan, B.V., Lalithambika, M. and Nair, C.G.R. (1992) Sintering Studies on Plastic Clays. Ceramics International, 18, 359-364.

https://doi.org/10.1016/0272-8842(92)90066-M

[4] Jordan, M.M., Boix, A., Sanfeliu, T. and de la Fuente, C. (1999) Firing Transformations of Cretaceous Clays Used in the Manufacturing of Ceramic Tiles. Applied Clay Science, 14, 225-234. https://doi.org/10.1016/S0169-1317(98)00052-0

[5] Jordan, M.M., Martín-Martín, J.D., Sanfeliu, T., Gómez-Gras, D. and De la Fuente, C. (2009) Mineralogy and Firing Transformations of Permo-Triassic Clays Used in the Manufacturing of Ceramic Tile Bodies. Applied Clay Science, 44, 173-177. https://doi.org/10.1016/j.clay.2009.01.018

[6] Rado, P. (1988) An Introduction to the Technology of Pottery. Pergamon Press, Oxford.

[7] Baccour, H., Medhioub, M., Jamoussi, F., Mhiri, T. and Daoud, A. (2008) Mineralogical Evaluation and Industrial Applications of the Triassic Clay Deposits, Southern Tunisia. Materials Characterization, 59, 1613-1622.

https://doi.org/10.1016/j.matchar.2008.02.008

[8] Vieira, C.M.F., Sanchez, R. and Monteiro, S.N. (2008) Characteristics of Clays and Properties of Building Ceramics in the State of Rio de Janeiro, Brazil. Construction and Building Materials, 22, 781-787.

https://doi.org/10.1016/j.conbuildmat.2007.01.006

[9] Meseguer, S., Sanfeliu, T. and Jordan, M.M. (2009) Classification and Statistical Analysis of Mine Spoils Chemical Composition from Oliete Basin (Teruel. NE Spain). Environmental Geology, 56, 1461-1466. https://doi.org/10.1007/s00254-008-1241-0

[10] Celik, H. (2010) Technological Characterization and Industrial Application of Two Turkish Clays for the Ceramic Industry. Applied Clay Science, 50, 245-254. https://doi.org/10.1016/j.clay.2010.08.005

[11] Diko, M.L., Ekosse, G.E., Ayonghe, S.N. and Ntasin, E.B. (2011) Physical Characterization of Clayey Materials from Tertiary Volcanic Cones in Limbe (Cameroon) for Ceramic Applications. Applied Clay Science, 51, 380-384. https://doi.org/10.1016/j.clay.2010.11.034

[12] Ngun, B.K., Mohamad, H., Sulaiman, S.K., Okada, K. and Ahmad, Z.A. (2011) Some Ceramic Properties of Clays from Central Cambodia. Applied Clay Science, 53, 33-41. https://doi.org/10.1016/j.clay.2011.04.017

[13] Ngon Ngon, G.F., Yongue Fouateu, R., Lecomte Nana, G.L., Bitom, D.L., Bilong, P. and Lecomte, G. (2012) Study of Physical and Mechanical Applications on Ceramics of the Lateritic and Alluvial Clayey Mixtures of the Yaoundé Region (Cameroon). 
Construction and Building Materials, 31, 294-299.

https://doi.org/10.1016/j.conbuildmat.2011.12.108

[14] Lisboa, J.V.V., Carvalho, J.M.F., Cunha, P.P. and Oliveira, A. (2013) Typological Classification of Clayey Raw Materials for Ceramics Manufacture, in the Tabua Region (Central Portugal). Bulletin of Engineering Geology and the Environment, 72, 225-232. https://doi.org/10.1007/s10064-013-0468-5

[15] Dondi, M., Raimondo, M. and Zanelli, Ch. (2014) Clays and Bodies for Ceramic Tiles: Reappraisal and Technological Classification. Applied Clay Science, 96, 91-109. https://doi.org/10.1016/j.clay.2014.01.013

[16] El Ouahabi, M., Daoudi, L. and Fagel, N. (2014) Preliminary Mineralogical and Geotechnical Characterization of Clays from Morocco: Application to Ceramic Industry. Clay Miner, 49, 35-51. https://doi.org/10.1180/claymin.2014.049.1.04

[17] Lahcen, D., Hicham, E.E., Latifa, S., Abderrahmane, A., Jamal, B., Mohamed, W., Meriam, E. and Nathalie, F. (2014) Characteristics and Ceramic Properties of Clayey Materials from Amezmiz Region (Western High Atlas, Morocco). Applied Clay Science, 102, 139-147. https://doi.org/10.1016/j.clay.2014.09.029

[18] Özkan, İ. (2014) Ceramic Properties of a Turkish Clay in the Aydın Region. Journal of Ceramic Processing Research, 15, 44-47.

[19] Boussen, S., Sghaier, D., Chaabani, F., Jamoussi, B. and Bennour, A. (2016) Characteristics and Industrial Application of the Lower Cretaceous Clay Deposits (Bouhedra Formation), Southeast Tunisia: Potential Use for the Manufacturing of Ceramic Tiles and Bricks. Applied Clay Science, 123, 210-221.

https://doi.org/10.1016/j.clay.2016.01.027

[20] Hein, A., Tsolakidou, A. and Mommsen, H. (2002) Mycenaean Pottery from the Argolid and Achaia-A Mineralogical Approach Where Chemistry Leaves Unanswered Questions. Archaeometry, 44, 177-186. https://doi.org/10.1111/1475-4754.t01-1-00051

[21] Hein, A., Day, P.M., Quinn, P.S. and Kilikoglou, V. (2004) The Geochemical Diversity of Neogene Clay Deposits in Crete and Its Implications for Provenance Studies of Minoan Pottery. Archaeometry, 46, 7-384. https://doi.org/10.1111/j.1475-4754.2004.00163.x

[22] Montana, G., Angel, M., Ontiveros, C., Polito, A.M. and Azzaro, E. (2011) Characterization of Clayey Raw Materials for Ceramic Manufacture in Ancient Sicily. Applied Clay Science, 53, 476-488. https://doi.org/10.1016/j.clay.2010.09.005

[23] Guggenheim, S. (2011) Introduction to the Properties of Clay Minerals. Department of Geological Sciences, University of Illinois, Chicago.

[24] Neyt, B., Braekmans, D., Poblome, J., Elsen, J., Waelkens, M. and Degryse, P. (2012) Long-Term Clay Raw Material Selection and Use in the Region of Classical/Hellenistic to Early Byzantine Sagalassos (SW Turkey). Journal of Archaeological Science, 39, 1296-1305. https://doi.org/10.1016/j.jas.2012.01.005

[25] Adelabu, O.S. (2012) Documentation, Application and Utilization of Clay Minerals in Kaduna State (Nigeria).

[26] Semiz, B. (2017) Characteristics of Clay-Rich Raw Materials for Ceramic Applications in Denizli Region (Western Anatolia). Applied Clay Science, 137, 83-93. https://doi.org/10.1016/j.clay.2016.12.014

[27] Al-Sarawi, A.M. (1982) Origin of the Jal A1 Zor Escarpment. Journal of the University of Kuwait (Science), 9, 151-162.

[28] Cox, P.T. and Rhoades, R.O. (1935) A Report on the Geology and Oil Prospects of Kuwait Territory. Unpublished Kuwait Oil Company Report, Geological Report No. $1,19 \mathrm{p}$. 
[29] Milton, D.I. (1965) Geology of the Arabian Peninsula Kuwait. United States Geological Society, Professional Paper 560-F, 7 p.

[30] Al-Sarawi, A.M. (1980) Tertiary Faulting beneath Wadi A1 Batin (Kuwait). GSA Bulletin, 91, 610-618. https://doi.org/10.1130/0016-7606(1980)91<610:TFBWAK>2.0.CO;2

[31] Bou-Rabee, F.A. (1986) The Geology and Geophysics of Kuwait. PhD Dissertation University of South Carolina, $150 \mathrm{p}$.

[32] Bou-Rabee, F.A. (1996) The Tectonic and Depositional History of Kuwait from Seismic Reflection Data. Journal of Petroleum Geology, 19, 183-198. https://doi.org/10.1111/j.1747-5457.1996.tb00424.x

[33] Warsi, W.E.K. (1990) Gravity Field of Kuwait and its Relevance to Major Geological Structures. American Association of Petroleum Geologists Bulletin, 74, 1610-1622.

[34] Henson, F.R.S. (1951) Observations on the Geology and Petroleum Occurrences of the Middle East. 3 rd World Petroleum Congress, The Hague, Vol. 1, 118-140.

[35] Fox, A.F. (1956) Oil Occurrences in Kuwait. Symposium sobre yacimientos de petroleoygas, 20 th Congress Geological International, Mexico, Vol. 2, 131-158.

[36] Fox, A.F. (1959) Some Problems of Petroleum Geology in Kuwait. Journal of the Institute of Petroleum, 45, 95-104.

[37] Fox, A.F. (1961) The Development of the Southeast Kuwait Oilfields. Institute Petroleum Review, 15, 373-379.

[38] Adasani, M. (1965) The Greater Burgan Field. 5th Arab Petroleum Congress, Cairo, 16-23 March 1965, 7-27.

[39] Adasani, M. (1967) The Northern Kuwait Oilfields. 6th Arab Petroleum Congress, Baghdad, 6-13 June 1967, 39 p.

[40] Adasani, M. (1985) The West Kuwait Oilfields. Ministry of Oil and Industry Report, $62 \mathrm{p}$.

[41] Milton, D.I. and Davies, C.C.S. (1965) Exploration and Development of the Raudhatain Field. Journal of the Institute of Petroleum, 51, 17-28.

[42] Nelson, P.H. (1968) Wapa Field-Kuwaitl Saudi Neutral Zone. 2nd Regional Technical Symposium, Dharan, 27 March 1968, 1-6. https://doi.org/10.2118/2371-MS

[43] Al-Rawi, M.M. (1981) Geological Interpretation of Oil Entrapment in the Zubair Formation Raudhatain Field. Middle East Technical Conference and Exhibition, Bahrain, 9-12 March 1981, Vol. 9591, 149-159. https://doi.org/10.2118/9591-MS

[44] Brennan, P. (1990) Raudhatain Field, Kuwait, Arabian Basin. In: Beaumont, E.A. and Foster, N.H., Eds., Structural Traps V, Treatise of Petroleum Geology, Atlas of Oil and Gas Fields, American Association of Petroleum Geologists, Tulsa, 187-210.

[45] Brennan, P. (1990) Greater Burgan Field. In: Beaumont, E.A. and Foster, N.H., Eds., Structural Traps I, Treatise of Petroleum Geology, Atlas of Oil and Gas Fields, American Association of Petroleum Geologists, Tulsa, 103-128.

[46] Al-Anzi, M. (1995) Stratigraphy and Structure of the Bahrah Field, Kuwait. In: Al-Husseini, M.I., Ed., Middle East Petroleum Geosciences, Gulf Petrol, Bahrain, 1, 53-64.

[47] Owen, R.M.S. and Nasr, S.N. (1958) Stratigraphy of the Kuwait Basra Area. In: Weeks, L., Ed., Habitat of Oil, American Association of Petroleum Geologists, Tulsa, $1252-1278$.

[48] Al-Sulaimi, S.J. and El-Rebba, M.S. (1994) Morphological and Morphostructural Features of Kuwait. Geomorphology, 11, 151-167. 
https://doi.org/10.1016/0169-555X(94)90079-5

[49] Khalaf, F.I., Gharib, I.M. and Al-Hashash, M. (1984) Types and Characteristics of the Recent Surface Deposits of Kuwait, Arabian Gulf. Journal of Arid Environment, 7, 9-33.

[50] El-Baz, F. (1994) Gulf War Disruption of the Desert Surface in Kuwait, the Gulf War and the Environment. Cordon and Breach Science Publishers, Philadelphia, 131-161.

[51] Al-Ghadban, A.N. and El-Sammak, A.A. (2005) Sources, Distribution and Composition of the Suspended Sediments, Kuwait Bay, Northern Arabian Gulf. Journal of Arid Environments, 60, 647-661. https://doi.org/10.1016/j.jaridenv.2004.07.017

[52] Nweke, E.S. and Ugwu, E.I. (2007) Analysis and Characterization of Clay Soil in Abakaliki, Nigeria. The Pacific Journal of Science and Technology, 8, 90-193.

[53] Dogan, C.P., Kwong, K.S. and Bennet, J.P. (2002) Improved Refractory Materials for Slagging Coal Gasifiers. Proceedings from the 27 th International Conference on Coal Utilization and Fuel Systems, Clearwater.

[54] Shichi, T. and Takagi, K. (2000) Clay Minerals as Photochemical Reaction Fields. Journal of Photochemistry and Photobiology C: Photochemistry Reviews, 1 , 113-130. https://doi.org/10.1016/S1389-5567(00)00008-3

[55] Nayak, P.S. and Singh, B.K. (2007) Instrumental Characterization of Clay by XRF, XRD and FTIR. Bulletin of Materials Science, 30, 235-238. https://doi.org/10.1007/s12034-007-0042-5

[56] Burhan, D. and Emin, C. (2010) The Clay Minerals Observed in the Building Stones of Aksaray-Guzelyurt Area (Central Anatolia-Turkey) and Their Effects. International Journal of the Physical Sciences, 5, 1734-1743.

[57] Murray, H.H. (2007) Applied Clay Mineralogy: Occurrences, Processing and Application of Kaolins, Bentonites, Palygorskite-Sepiolite, and Common Clays. Elsevier, Amsterdam.

[58] Kabeto, K., Zeneb, A., Bheemalingeswara, K., Atshbeha, K., Gebresilassie, S. and Amare, K. (2012) Mineralogical and Geochemical Characterization of Clay and Lacustrine Deposits of Lake Ashenge Basin, Northern Ethiopia: Implication for Industrial Applications. Momona Ethiopia Journal of Science, 2, 111-129.

[59] Carroll, D. (1970) Clay Minerals in Arctic Ocean Sea-Floor Sediments. Journal of Sedimentary Petrology, 40, 814-821.

[60] Biscaye, P.E. (1965) Mineralogy and Sedimentation of Recent Deep-Sea Clay in the Atlantic Ocean and Adjacent Seas and Oceans. Geological Society of America Bulletin, 76, 803-831.

[61] Malins, J. and Gray, C. (1995) Appropriate Research Methodologies for Artists, Designers \& Craftspersons: Research as a Learning Process. Katie Bunnell \& Eleanor Wheeler. The Centre for Research in Art \& Design, Gray's School of Art, Faculty of Design, The Robert Gordon University, Aberdeen.

[62] Halwagy, R. and Halwagy, M. (1974) Ecological Studies on Desert of Kuwait. II. The Vegetation Journal of the University of Kuwait, 1, 87-95.

[63] Folorunso, D.O., Olubambi, P. and Borode, J.O. (2014) Characterization and Qualitative Analysis of Some Nigerian Clay Deposits for Refractory Applications. IOSR Journal of Applied Chemistry, 7, 40-47. https://doi.org/10.9790/5736-7914047

[64] Hoffman, J. and Hower, J. (1979) Clay Mineral Assemblages as Low Grade Metamorphic Geothermometers: Application to the Thrust Faulted Disturbed Belt of Montana. In: Scholle, P.A. and Schluger, P.S., Eds., Aspects of Diagenesis, SEPM 
Spec. Publ., Vol. 26, 55-79.

[65] Chamley, H. (1989) Clay Sedimentology. Springer-Verlag, Berlin. https://doi.org/10.1007/978-3-642-85916-8

[66] Ghandour, I.M., Abd El-Hameed, A.T., Faris, M., Marzouk, A. and Maejima, W. (2004) Textural, Mineralogical and Microfacies Characteristics of the Lower Paleogene Succession at the Nile Valley and Kharga Oasis Regions, Central Egypt. Journal of Geosciences, 47, 3953. 